\title{
Nucleoside transporter proteins as biomarkers of drug responsiveness and drug targets
}

\author{
Marçal Pastor-Anglada ${ }^{1,2}$ and Sandra Pérez-Torras ${ }^{1,2} *$ \\ Molecular Pharmacology and Experimental Therapeutics, Department of Biochemistry and Molecular Biology, Institute of Biomedicine, University of \\ Barcelona, Barcelona, Spain \\ ${ }^{2}$ Oncology Program, CIBER ehd, National Biomedical Research Institute on Liver and Gastrointestinal Diseases, Instituto de Salud Carlos III, Barcelona, Spain
}

\section{Edited by:}

Harry P. De Koning, University of Glasgow, UK

\section{Reviewed by:}

Stanislav Yanev, Bulgarian Academy of Sciences, Bulgaria

Andrei Adrian Tica, University of

Medicine-Craiova, Romania

\section{*Correspondence:}

Sandra Pérez-Torras, Molecular

Pharmacology and Experimental

Therapeutics, Department of

Biochemistry and Molecular Biology,

Institute of Biomedicine, University of

Barcelona, Avenida/Diagonal 643,

Prevosti Building Floor-1,

08028 Barcelona, Spain

e-mail: s.perez-torras@ub.edu
Nucleoside and nucleobase analogs are currently used in the treatment of solid tumors, lymphoproliferative diseases, viral infections such as hepatitis and AIDS, and some inflammatory diseases such as Crohn. Two gene families are implicated in the uptake of nucleosides and nucleoside analogs into cells, SCL28 and SLC29. The former encodes hCNT1, hCNT2, and hCNT3 proteins. They translocate nucleosides in a $\mathrm{Na}^{+}$coupled manner with high affinity and some substrate selectivity, being hCNT1 and hCNT2 pyrimidine- and purine-preferring, respectively, and hCNT3 a broad selectivity transporter. SLC29 genes encode four members, being hENT1 and hENT2 the only two which are unequivocally implicated in the translocation of nucleosides and nucleobases (the latter mostly via hENT2) at the cell plasma membrane. Some nucleoside-derived drugs can also interact with and be translocated by members of the SLC22 gene family, particularly hOCT and hOAT proteins. Inter-individual differences in transporter function and perhaps, more importantly, altered expression associated with the disease itself might modulate the transporter profile of target cells, thereby determining drug bioavailability and action. Drug transporter pharmacology has been periodically reviewed. Thus, with this contribution we aim at providing a state-of-the-art overview of the clinical evidence generated so far supporting the concept that these membrane proteins can indeed be biomarkers suitable for diagnosis and/or prognosis. Last but not least, some of these transporter proteins can also be envisaged as drug targets, as long as they can show "transceptor" functions, in some cases related to their role as modulators of extracellular adenosine levels, thereby providing a functional link between $\mathrm{P} 1$ receptors and transporters.

Keywords: nucleoside transporter, nucleoside analog, biomarker, cancer, ENT1, viral diseases
Nucleosides and nucleotides play important roles in cell physiology both as nutrients and modulators of cellular homeostasis. They are implicated in crucial processes such as DNA and RNA synthesis, cell signaling, and metabolic regulation. Moreover, nucleoside and nucleobase analogs are currently used in the treatment of solid tumors, lymphoproliferative diseases, viral infections such as hepatitis and AIDS, and some inflammatory diseases such as Crohn (Minuesa et al., 2011; Jordheim et al., 2013). Nucleosides and nucleoside-derived drugs are hydrophilic molecules and diffuse, if they can, slowly across cell membranes. Thus, to exert their physiological and cytotoxic effects, specific membrane transporters that mediate their flux across cell membranes are required. Nucleoside transporters (NTs) are integral membrane proteins implicated in the salvage of

\footnotetext{
Abbreviations: CLL, chronic lymphocytic leukemia; CMV, cytomegalovirus; CNT concentrative nucleoside transporter; DFS, disease free survival; ENT, equilibrative nucleoside transporter; $\mathrm{HBV}$, hepatitis B virus; $\mathrm{HCV}$, hepatitis $\mathrm{C}$ virus; HIV, human immunodeficiency virus; HSV, herpes simplex virus; NBTI, nitrobenzylthioinosine; NT, nucleoside transporter; OAT, organic anion transporter; OCT, organic cation transporter; OCTN, organic cation/carnitine transporters; OS, overall survival; PEPT, peptide transporter; SLC, solute carrier transporter; SVR, sustained virological response.
}

natural nucleobases and nucleosides for nucleic acid synthesis. NTs belong to solute carrier families 28 and 29 (SLC28 and SLC29), which encode human concentrative nucleoside transporters (hCNT) and equilibrative nucleoside transporter proteins (hENTs), respectively (Molina-Arcas et al., 2009; Pastor-Anglada et al., 2009; Cano-Soldado and Pastor-Anglada, 2012; MolinaArcas and Pastor-Anglada, 2013). However, the chemical modifications of the nucleoside analogs can alter their ability to interact with canonical transporter proteins implicated in the uptake of natural nucleosides. The paradigm of this concept is the lack of interaction of hCNT1 with those antiviral drugs lacking the $3^{\prime} \mathrm{OH}$ of the ribose, which appears to be an essential structural requirement for substrate translocation (Cano-Soldado et al., 2004). In fact, the structural requirements for nucleoside-NT interactions have already been reviewed elsewhere (Cano-Soldado and Pastor-Anglada, 2012). Therefore, in some cases additional carrier proteins become major players in drug bioavailability, and likely, drug action. In this sense, members of the SLC22 gene family, which encode human organic cation transporters, (hOCTs) and organic anion transporters (hOATs) are also implicated in the uptake of nucleoside-derived drugs (Minuesa etal., 2011). Moreover, although both hENT1 and hENT2 have been reported 
to translocate some nucleobases (Yao et al., 2011), other transporter proteins might contribute to the uptake of purine and pyrimidine nucleobases into cells despite the molecular entity behind them still have to be identified (Wallace et al., 2002; Quashie et al., 2010).

\section{NUCLEOSIDE-DERIVED DRUG TRANSPORTERS SLC28}

The three human CNT proteins (hCNTs) mediate the unidirectional flow of nucleosides in an energy-costly process coupled to the influx of sodium ions. All three members of the SLC28 gene family accept uridine as substrate, but differ in their selectivity for other substrates. Thus, hCNT1 prefers pyrimidine nucleosides, hCNT2 purine nucleosides and uridine, and hCNT3 transports both pyrimidine and purine nucleosides. Importantly, they all have the ability of translocating selected nucleosidederivatives currently used in anticancer and antiviral therapies, being major determinants of drug action (Huber-Ruano and Pastor-Anglada, 2009; Errasti-Murugarren and Pastor-Anglada, 2010). The sodium/nucleoside coupling ratio of hCNT1 and hCNT2 is $1: 1$, while hCNT3 shows a 2:1 stoichiometry (Smith etal., 2004, 2007). Interestingly, hCNT3 is the only transporter in this family able to accept protons as driving force (Smith et al., 2005; Gorraitz etal., 2010). Based upon its broad selectivity and highly potential concentrative activity, hCNT3 is considered to be a major player in nucleoside-derived drug uptake.

hCNT proteins, initially thought to be expressed almost exclusively in polarized epithelia, are in fact broadly expressed but not ubiquitous. In most polarized epithelia, these proteins localize at the apical membrane, thus facilitating vectorial flux of nucleosides across the barriers (Mangravite et al., 2001, 2003; Lai et al., 2002; Errasti-Murugarren et al., 2007). In fact, CNTs are expressed in all tissues which are considered to be relevant for drug pharmacokinetics (i.e., intestine, kidney, liver, and blood brain barrier).

\section{SLC29}

The human ENT proteins (hENTs) family contain four members, hENT1-4 (Molina-Arcas et al., 2009; Pastor-Anglada et al., 2009; Cano-Soldado and Pastor-Anglada, 2012; Molina-Arcas and Pastor-Anglada, 2013). hENTs, except hENT4, mediate the facilitative transport of natural nucleosides with broad selectivity but relatively lower affinity than their CNT-type counterparts (Baldwin et al., 2004; Young et al., 2008). In fact, hENT1-3 proteins transport both purine and pyrimidine nucleosides, despite significant differences in substrate selectivity. The two best-characterized transporters hENT1 and hENT2 can be distinguished on the basis of their sensitivity to inhibition by the nucleoside analog NBTI, with hENT1 being much more sensitive than hENT2. Both transporters are also inhibited by vasodilation potentiators including dipyridamole and dilazep, being hENT1 also more sensitive than hENT2 (Visser et al., 2002). Additionally, hENT2 transports nucleobases (Osses etal., 1996). Moreover, hENT1 has recently been shown to transport some nucleobases, albeit with low kinetic efficiencies compared to hENT2 (Yao et al., 2011). hENT3 can also transport the nucleobase adenine and is not sensitive to inhibition by NBTI. This transporter protein was initially reported to be localized in lysosomes and, more recently, identified in mitochondria (Govindarajan et al., 2009). hENT3 is the only NT studied to date that has been associated with inherited human diseases. Several syndromes, including the $\mathrm{H}$ syndrome (Molho-Pessach et al., 2008, 2014; Bolze et al., 2012; Huber-Ruano etal., 2012) and the pigmented hypertrichosis with insulin dependent diabetes (PHID) syndrome (Spiegel et al., 2010) have been associated with mutations in the SLC29A3 gene. Finally, hENT4 may not be considered a "canonical" NT because it mostly transports organic cations, although it is a suitable adenosine transporter under acidic $\mathrm{pH}$ conditions (Barnes et al., 2006).

hENT1 and hENT2 are ubiquitously distributed, but differ in abundance among tissues and cell types (Baldwin et al., 2004). These transporters seem to be mainly, but not exclusively, localized at the basolateral side of polarized epithelial cells (Lai et al., 2002; Mangravite et al., 2003), contributing to the vectorial flux of nucleosides across these barriers.

\section{SLC22}

The organic ion transporter family, SLC22, includes 22 transporters. Within the family, there are several subfamilies, which consist of members that cluster together based on sequence homology, including the OATs, the OCTs, and the OCTNs.

hOCT1, hOCT2, and hOCT3 are encoded by genes SLC22A1-3 (Koehler etal., 1997; Grundemann etal., 1998; Grundemann and Schomig, 2000). Transport of organic cations by hOCTs is electrogenic, sodium-independent, and bidirectional across the plasma membrane. The driving force is supplied by the electrochemical gradient of the transported organic cation. These proteins display broad substrate selectivity, transport positively charged compounds with a relative molecular mass below 500 and target both endogenous (hormones, neurotransmitters, creatinine, and others) and exogenous molecules (antiviral, antidiabetic, antiemetic, cytostatic among other drugs). hOCTs exhibit broad tissue distribution and are expressed in epithelial cells and neurons (Koepsell et al., 2003; Muller et al., 2005), whereas its occurrence in immune system cells has also been reported (Minuesa et al., 2008).

hOAT1, hOAT2, hOAT3, and hOAT4 are encoded by genes SLC22A6-8 and 11 (Rizwan and Burckhardt, 2007; VanWert et al., 2010). hOATs exchange extracellular against intracellular divalent organic anions. The concentration of the intracellular organic anion must be higher in the cytosol than outside the cell in order to drive the uptake of organic anions through OATs. This concentration difference is maintained by sodium-coupled anion transporters located at the same membrane as the respective OATs. These proteins accept a huge variety of chemically unrelated endogenous and exogenous organic anions including many drugs (Koepsell, 2013). OATs play a pivotal role in renal excretion of water-soluble, negatively charged organic compounds including endogenous waste products, numerous drugs, and drug metabolites. OATs are located at the plasma membrane of epithelial cells of proximal tubules, the site of efficient renal organic anion secretion. Selected OATs are present also outside the kidneys, e.g., in liver, 
placenta, nasal epithelium, and brain, where they serve special functions (VanWert et al., 2010; Burckhardt, 2012; Koepsell, 2013).

Although the SLC22 family include other members, those are the ones that are most likely to transport nucleoside analogs (Errasti-Murugarren and Pastor-Anglada, 2010; Minuesa et al., 2011; Koepsell, 2013).

\section{NUCLEOSIDE ANALOGS IN MEDICINAL CHEMISTRY NUCLEOSIDE ANALOGS IN CANCER TREATMENT}

Nucleoside analogs were among the first chemotherapeutic agents used in the treatment of malignant diseases and today their activity is well established, showing a broad clinical use. The research on purines and purine analogs was recognized with the Nobel Prize in Physiology or Medicine in 1988. In the early 50' Gertrude Elion and George Hitchings developed thioguanine and 6-mercaptopurine (6-MP) against leukemia. Later, they also developed, azathioprine, a drug that prevents rejection of transplanted organs and allopurinol which is used in the treatment of gout. Essentially, their research involved the rational development of a series of new drugs based upon the understanding of basic biochemical and physiological processes (Elion, 1989). (http://www.nobelprize.org/nobel_prizes/medicine/laureates/ 1988/press.html).

The anticancer nucleosides include analogs of pyrimidine and purine nucleosides (Table 1). The basic mechanism of action of most nucleoside analogs used in cancer treatment is similar (Parker, 2009). They get into cells where they are converted to analogs of cellular nucleotides (often the real active drugs) by enzymes of either the purine or the pyrimidine metabolic pathways. Nucleotide drugs can then be incorporated into nucleic acids and, in most cases, inhibit enzymes implicated in DNA synthesis, causing DNA damage and induction of apoptosis. Selective differences among them can also be found and they often rely upon their ability to interact with enzymes of the purine and pyrimidine salvage pathways.

In general, purine nucleosides work almost exclusively against hematological malignancies, while pyrimidine analogs typically show efficacy against both blood cancers and solid tumors. NTs display different affinities for the analogs and their substrate selectivity has been comprehensively reviewed elsewhere. Thus, the tissue distribution of the transporters has a large impact on their therapeutic effect. As expected, purine-based nucleoside analogs such as fludarabine, cladribine, and clofarabine are substrates for

Table 1 | Nucleoside analogs used for cancer treatment.

\begin{tabular}{|c|c|c|c|c|c|}
\hline Drug name & Therapeutic use & Analogous to & $\begin{array}{l}\text { FDA } \\
\text { approval }\end{array}$ & Identified uptake transporter & Reference \\
\hline Mercaptopurine & Lymphoproliferative diseases & Purine & 1953 & hCNT3, hENT1, hENT2 & $\begin{array}{l}\text { Fotoohi etal. (2006), Yao } \\
\text { etal. (2011) }\end{array}$ \\
\hline Cytarabine & Lymphoproliferative diseases & Pyrimidine & 1969 & hCNT1, hENT1, hENT2 & $\begin{array}{l}\text { Smith etal. (2004), Clarke } \\
\text { et al. (2006) }\end{array}$ \\
\hline Fludarabine & Lymphoproliferative diseases & Purine & 1991 & hCNT2, hCNT3, hENT1, hENT2 & King et al. (2006) \\
\hline Pentostatin & Lymphoproliferative diseases & Purine & 1991 & hENT1, hENT2 & Wiley et al. (1991) \\
\hline Cladribine & Lymphoproliferative diseases & Purine & 1993 & hCNT2, hCNT3, hENT1, hENT2 & King et al. (2006) \\
\hline Azacitidine & Lymphoproliferative diseases & Pyrimidine & 2004 & $\begin{array}{l}\text { hCNT1, hCNT2, hCNT3, hENT1, } \\
\text { hENT2, hENT3, hENT4 }\end{array}$ & $\begin{array}{l}\text { Rius et al. (2009), } \\
\text { Damaraju etal. (2012) }\end{array}$ \\
\hline Clofarabine & Lymphoproliferative diseases & Purine & 2004 & hCNT2, hCNT3, hENT1, hENT2 & King et al. (2006) \\
\hline Nelarabine $(A r a G)^{1}$ & Lymphoproliferative diseases & Purine & 2005 & & \\
\hline Decitabine & Lymphoproliferative diseases & Pyrimidine & 2006 & hENT1, hENT2 & $\begin{array}{l}\text { Damaraju et al. (2012), } \\
\text { Arimany-Nardi et al. (2014) }\end{array}$ \\
\hline Floxuridine & Solid tumors & Pyrimidine & 1970 & hCNT1, hCNT2, hCNT3 & $\begin{array}{l}\text { Lang etal. (2001), Smith } \\
\text { etal. (2004), Hu etal. } \\
\text { (2006) }\end{array}$ \\
\hline Gemcitabine & Solid tumors & Pyrimidine & 1996 & $\begin{array}{l}\text { hCNT1, hCNT3, hENT1, hENT2, } \\
\text { hENT3 }\end{array}$ & $\begin{array}{l}\text { Mackey etal. (1999), Hu } \\
\text { etal. (2006), Govindarajan } \\
\text { etal. (2009) }\end{array}$ \\
\hline Capecitabine (5-DFUR) ${ }^{2}$ & Solid tumors & Pyrimidine & 1998 & & \\
\hline 5-Fluorouracil & Solid tumors & Pyrimidine & 1998 & hENT1, hENT2, hOAT2 & $\begin{array}{l}\text { Kobayashi etal. (2005), Yao } \\
\text { etal. (2011) }\end{array}$ \\
\hline
\end{tabular}

\footnotetext{
${ }^{1}$ Nelarabine is a prodrug of AraG, which is translocated by hENT1 and hENT2 (Prus et al., 1990).

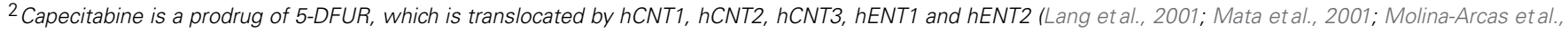
2006; Errasti-Murugarren etal., 2007). In gray, transporters for which weak substrate interaction has been reported.
} 
hENT1, hENT2, hCNT3, and hCNT2 (Lang et al., 2001; MolinaArcas etal., 2005; King et al., 2006; Owen et al., 2006; ErrastiMurugarren and Pastor-Anglada, 2010). Conversely, pyrimidine analogs such as gemcitabine, cytarabine, and azacytidine are transported by hCNT1 in addition to hENT1, hENT2, and hCNT3 (Mackey etal., 1999; Smith etal., 2004; Clarke etal., 2006; Endo et al., 2007; Errasti-Murugarren et al., 2007; ErrastiMurugarren and Pastor-Anglada, 2010; Arimany-Nardi et al., 2014). Nucleobases, such as 5-fluorouracil and 6-MP have also been reported to interact with hENT1 and hENT2 proteins, although their affinity constants are within the $\mathrm{mM}$ range (Yao et al., 2011).

\section{NUCLEOSIDE ANALOGS IN VIRAL DISEASES}

During the past two decades, antiviral drugs have become crucial in the management of several viral infections, including HSV, HIV, HBV, HCV, and CMV infections. Prominent among these drugs are nucleoside derivatives(Table 2 ), which can act as potent antiviral agents owing to their ability to inhibit viral DNA polymerases and reverse transcriptases, which have key roles in the various viral life cycles. Antiviral nucleoside and nucleotide analogs are structurally more diverse than anticancer nucleoside analogs, as they consist of nucleosides, nucleotides, and acyclic nucleosides (De Clercq and Holy, 2005). Acyclic nucleosides have been approved for the treatment of various DNA virus infections (cidofovir), hepatitis B (adefovir), and AIDS (tenofovir).

Some NT proteins and particularly, but not exclusively, the broad selective transporter hCNT3 can interact and translocate different types of antiviral drugs, such as ribavirin and zidovudine, among others (Hu et al., 2006; Errasti-Murugarren etal., 2007). However, hOCT proteins also appear to interact with these drugs with high affinity, lamivudine being a substrate and tenofovir, abacabir, and zidovudine high affinity inhibitors of hOCT1, hOCT2, and hOCT3 (Minuesa et al., 2009). This might be particularly relevant in the clinics, because AIDS patients are under combined therapy and hOCT1 and hOCT3 are highly expressed in target cells (i.e., $\mathrm{CD}^{+} \mathrm{T}$ cells; Minuesa et al., 2008). Moreover, hOCTs (particularly hOCT1) are highly polymorphic proteins, with some variants showing high allelic frequency and already shown to be relevant in the pharmacokinetics of other drugs such as metformin (Errasti-Murugarren and Pastor-Anglada, 2010). Other SLC22 members might also interact with nucleoside-derived drugs (Errasti-Murugarren and Pastor-Anglada, 2010; Cano-Soldado and Pastor-Anglada, 2012), whereas for novel drugs at the pre-clinical stages, or even in the clinics such as the pronucleotide sofosbuvir, the best candidates to mediate their cellular uptake still have to be identified.

\section{NUCLEOSIDE ANALOGS IN INFLAMMATORY DISEASES}

The thiopurines, 6-MP, and its pro-drug azathioprine (AZA) have been a cornerstone of medical management of patients with inflammatory bowel disease (IBD) and many rheumatoid disorders.

Thiopurines are metabolized to their end products, 6-methymercaptopurine (6-MMP) and the 6-thioguanine nucleotides (6-TGN). Although these nucleotides disturb proper DNA synthesis it has not been conclusively shown, that 6-TGN are the only molecules responsible for proper action. However, immunosuppressive function seems to be mediated in part by induction of apoptosis in lymphocytes. A correlation of therapeutic benefit and 6-TGN levels has been put into question. Although thiopurines are widely used, several safety concerns remain regarding the optimal treatment regimens. Thioguanine has been proposed as an alternative to overcome such problems, as it skips the metabolic conversion to 6-MMP which is responsible for hepatotoxicity (Bar et al., 2013; Frei et al., 2013; Friedman et al., 2014).

\section{TRANSPORTERS AS BIOMARKERS}

Transporter function may be influenced by multiple factors and is likely to be highly variable among individuals (Nies et al., 2009; Sakamoto et al., 2013; Prasad et al., 2014). Thus, interindividual heterogeneity in response to therapy can be somehow related to inherent transporter function variability among patients and also to altered transporter expression in target cells, even as a result of the disease itself. In this context, transportome profiles and their associated pharmacogenetics might prove suitable for the prediction of treatment outcomes, and ideally should be helpful in decision making processes, such as choice of treatment (drug and dose) and in anticipating drug-drug interactions when patients face drug combination schedules. In fact, drug transporters can often be inhibited by numerous compounds, either other drugs or endogenous substrates, typically by competition for recognition and binding. These interactions may even result in altered drug pharmacokinetics. Genetic heterogeneity of the transporter-encoding genes may also determine variable transporter function, either by increasing or by reducing the individual overall exposure to a substrate, also depending upon the tissue expression and localization of particular transporters.

In summary, inter-individual differences in transporter expression and function and, perhaps more importantly, altered expression either due to the oncogenic process itself, to viral infection or to inflammation might modulate the transporter profile of target cells, thereby determining drug bioavailability and action.

\section{BIOMARKERS OF DRUG SUSCEPTIBILITY}

As mentioned above, NT proteins are necessary for nucleoside analogs to enter into cells and exert their pharmacological action. The analysis of the role played by NTs in drug sensitivity and clinical outcomes of cancer patients initially focused on lymphoproliferative diseases.

Leukemic cells express both CNTs and hENTs and the analysis of these proteins in cells from 22 patients with primary CLL cells similarly expressed hENT1, hENT2, hCNT2, and hCNT3 mRNAs. However, fludarabine accumulation in CLL cells is mainly mediated by hENT1 and hENT2 (Molina-Arcas et al., 2003). Moreover, fludarabine transport correlates with hENT2 protein expression and activity, whereas in Mantle Cell Lymphoma (MCL) hENT1 correlates with ex vivo gemcitabine sensitivity (Marce et al., 2006).

Furthermore, data suggest that hENT1 expression influences response to cytarabine, but not sufficient to support its use as 
Table 2 | Nucleoside analogs used as antiviral agents.

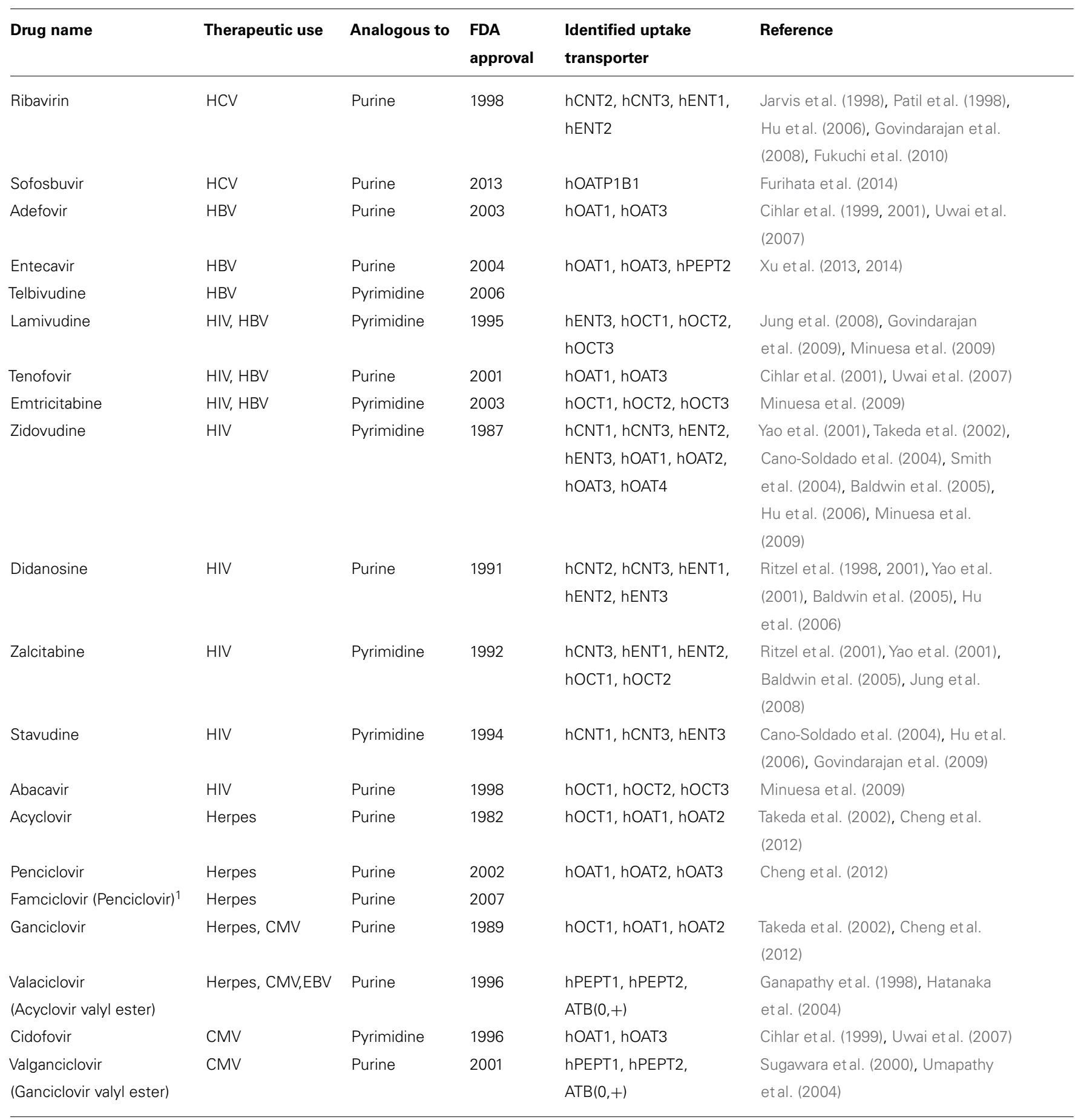

${ }^{1}$ Famciclovir is a prodrug of Penciclovir.

In gray, transporters where only interaction has been demonstrated.

a biomarker for guiding treatment in Acute Myeloid Leukemia (AML). In any case, permeant nucleoside analogs have been designed as a way to bypass NT function. Thus the activity of elacytarabine (the elaidic acid ester derivative of cytarabine) is not significantly predicted by the hENT1 expression level (Rizzieri et al., 2014).
To date, most studies in solid tumors focused on hENT1 levels and clinical response to gemcitabine, mainly in pancreatic cancer (Table 3). Comprehensive in vitro evidence supports the view that hENT1 activity is a key determinant of gemcitabine action. Overexpression of hENT1 enhances gemcitabine response in human pancreatic cancer, and cells lacking hENT1 expression are highly 
Table 3 | hENT1 expression and clinical response.

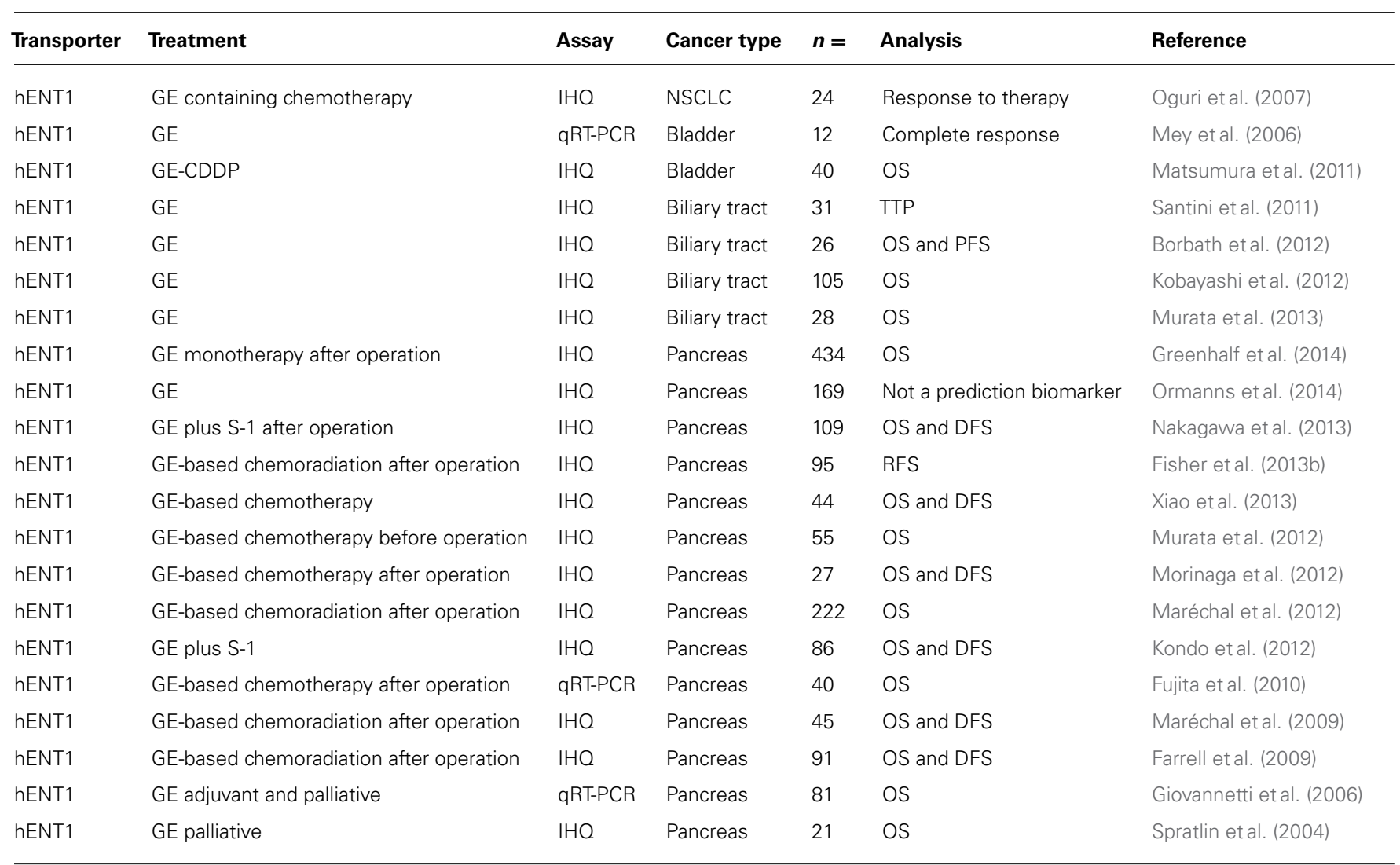

resistant to gemcitabine (Mori et al., 2007; Perez-Torras et al., 2008, 2013). There is increasing evidence supporting the view that hENT1 is a predictive biomarker for the use of gemcitabine. Several studies have explored hENT1 expression in gemcitabine-treated solid tumors with various techniques (immunohistochemistry and qRT-PCR) and different treatment regimens trying to establish correlations with patient outcomes. The first studies demonstrated that hENT1 expression was prognostic in pancreatic cancer, but this research included both early (resected) and advanced disease, which were mostly treated with gemcitabine (Spratlin et al., 2004; Giovannetti et al., 2006). Later, in patients with pancreatic cancer from a randomized phase III RTOG 9704 study, hENT1 expression was associated with increased OS and DFS in patients who received adjuvant gemcitabine chemotherapy, but not on those who received 5-fluorouracil (Farrell et al., 2009). Moreover, in an analysis of 45 pancreatic cancer patients treated with postoperative adjuvant gemcitabine-based chemoradiation therapy, patients with high hENT1 expression had significantly longer DFS and OS than those with low hENT1 expression, and hENT1 expression was the only independent predictor for DFS and OS (Maréchal et al., 2009). Additional studies conducted up to now have provided encouraging but not yet convincing evidence of the use of this transporter as a suitable biomarker (Fujita et al., 2010; Kim et al., 2011; Kawada et al., 2012; Kondo et al., 2012; Maréchal et al., 2012; Morinaga et al., 2012; Murata et al., 2012; Fisher et al., 2013b; Nakagawa et al., 2013; Xiao et al., 2013). This is probably because they have been mostly retrospective and have used non-randomized series of patients. On the contrary, only a few studies have provided no evidence supporting the use of hENT1 as a predictive biomarker for gemcitabine efficacy in a neoadjuvant gemcitabinebased chemoradiation setting (Kawada et al., 2012) and in patients with advanced pancreatic cancer (Ormanns et al., 2014). However, none of the latter studies truly tested gemcitabine monotherapy in a defined group of patients. Recently, hENT1 expression was determined in a large unbiased group of patients that were given gemcitabine monotherapy (ESPAC3 trial), confirming its role as a predictive marker in gemcitabine-treated but not 5-fluorouraciltreated patients. This suggests that gemcitabine should not be used for patients with low tumor hENT1 expression (Greenhalf et al., 2014). Nevertheless, it cannot be ruled out the fact that differences among studies should also be explained by the tools used in this type of analysis. In this sense, it has been recently stated that the two antibodies used to detect hENT1 are not equivalent (Svrcek et al., 2014).

Interestingly, correlations between intratumoral hENT1 expression and responsiveness to gemcitabine have also been reported to occur in other types of malignant tumors. Responses to gemcitabine-based chemotherapy were evident in patients with high hENT1 expression but not in patients without hENT1 expression in an analysis of 24 patients with non-small cell lung cancer (Oguri etal., 2007). In bladder cancer, a first study with 12 cancer specimens showed a significant correlation between gemcitabine chemotherapy outcome and hENT1 expression (Mey etal., 2006). Later, the OS of patients treated 
with a gemcitabine-/cisplatin-based combination chemotherapy was significantly higher in patients with high hENT1 expression (Matsumura et al., 2011). In addition, a few studies in biliary cancer have shown an association between hENT1 expression, as determined by immunohistochemistry, and chemosensitivity to gemcitabine (Santini et al., 2011; Borbath et al., 2012; Kobayashi et al., 2012; Murata et al., 2013).

\section{BIOMARKER OF PROGNOSIS}

Besides the role of NT proteins as biomarkers of drug susceptibility discussed above, NT expression by itself might be a biomarker of disease prognosis, although available data are controversial so far. This is due to the fact that almost all studies have included treated-patients. Indeed, hENT1 itself has been related to epithelial mesenchymal transition (EMT) probably independently of its role as a drug transporter (Guillen-Gomez et al., 2012; Lee et al., 2014). Thus, it is likely that these proteins can also serve as prognostic biomarkers. Although several studies analyzed the prognostic value of intratumoral hENT1 expression in patients who had not received gemcitabine chemotherapy, in many of them it is not possible to discriminate between a therapeutic predictive effect and a disease prognostic effect for hENT1 expression due to the patient cohort choice, often based on retrospective analysis. A retrospective analysis of 111 patients with resected gastric cancer who had not received gemcitabine-based chemotherapy revealed that patients with high hENT1 expression had a shorter OS or DFS than those with low hENT1 expression (Santini et al., 2010). Similar results were also reported in 41 patients with ampullary cancer (Santini et al., 2008). In ampullary carcinoma, hENT1 expression and proliferation index were found to be dependent on the histological subtypes, suggesting a key role of hENT1 in tumor growth (Perrone et al., 2010). In biliary tract malignancies, high expression of hENT1 was correlated with improved OS, although the study was performed in 63 patients including intrahepatic, hilar, or distal cholangiocarcinoma and gallbladder carcinoma and a small group of patients within this cohort had been treated with nucleoside analogs (Fisher et al., 2013a). In addition, in a study with 84 pancreatic cancer patients, low expression of hENT1 was associated with shorter OS and progression free survival (PFS) independently of gemcitabine treatment (Kim et al., 2011). In an attempt to clarify this point, Greenhalf et al. (2014) examined the expression of hENT1 combining the observation arms from the ESPAC1 and ESPAC3 trials that were specifically randomized to no adjuvant treatment. Although the resultant number of cases investigated was small, there was no evidence to support hENT1 expression levels per se as indicative of OS (Greenhalf et al., 2014). However, further studies on a larger number of patients with various cancers are needed to clarify the role of hENT1 as a prognostic biomarker. Furthermore, the analysis of NTs expression in nearly 300 gynecologic tumors (ovary, endometrium, and uterine cervix carcinomas) showed loss of hCNT1 in a much higher number of cases than hENT1 and hENT2 and, this loss highly correlated with poor prognosis histotypes (Farre et al., 2004). In breast cancer, hCNT1 alone exhibited prognostic value for DFS and risk of relapse (Gloeckner-Hofmann et al., 2006).
A major bottleneck in the interpretation of the available data is the fact that almost all the studies addressed to determine the role of NTs as prognosis biomarkers in cancer analyzed different grades of the disease without a direct comparison with healthy tissue.

\section{GENETIC HETEROGENEITY AS BIOMARKER}

Compared to other drug transporter encoding-genes, neither SLC28 nor SLC29 genes appear to be highly polymorphic in humans (Errasti-Murugarren and Pastor-Anglada, 2010). On the contrary, hOCTs are highly polymorphic proteins, with some variants showing high allelic frequency in humans, being relevant to the pharmacokinetics of selected drugs such as metformin (Errasti-Murugarren and Pastor-Anglada, 2010).

Pharmacogenetic studies of hENT1 have not clearly identified yet any clinical relevance of the inter-individual sequence variations in the hENT1 encoding gene (SLC29A1). Although single nucleotide polymorphisms (SNPs) in hENT1 have been identified, none have demonstrated functional consequences in terms of drug uptake or accumulation (Osato et al., 2003; Kim et al., 2006; Myers et al., 2006). However, a recent study of 154 patients treated with neoadjuvant gemcitabine suggested that a combined assessment of six SNPs, including the hENT1 T-549C allele and hENT1 C913T allele, did correlate to OS (Okazaki et al., 2010). While multiple alternatively spliced variants encoding hENT1 have been identified, they have not been shown to have clinical relevance so far. As for hENT1, hENT2 also shows different spliced variants, some of them likely to be translated into proteins, although their physiological relevance is also unknown (Mangravite et al., 2003). Regarding the other members of the SLC29 gene family, as mentioned above, hENT3 has been directly implicated in the pathogenesis of human disease. Loss-of-function mutations in the hENT3 encoding gene have been associated with familial RosaiDorfman disease, Faisalabad histiocytosis, $\mathrm{H}$ syndrome, and PHID (Molho-Pessach et al., 2008; Cliffe et al., 2009; Kang et al., 2010; Morgan et al., 2010; Spiegel et al., 2010; Avitan-Hersh et al., 2011). Despite some controversy about the intracellular location of this transporter protein, it has recently been shown that ENT3 null mice develop defects in the lysosomal system, causing ineffective apoptotic cell clearance and increased M-CSF signaling which contribute to increase macrophage number and histiocytosis (Hsu et al., 2012).

Although hCNTs do not appear to be particularly variable at the gene level, some polymorphisms have been identified and supposed to have clinical relevance (Errasti-Murugarren and Pastor-Anglada, 2010). Functional complexity of selected polymorphic variants can be paradigmatic, as for the Spanish hCNT3 variant (hCNT3 Cys602Arg) which shows variable affinities for hCNT3 substrates, apparent loss of interaction with one of the two $\mathrm{Na}^{+}$ions being translocated along with the drug, and lipid raft missorting of the mutated variant, thereby dramatically affecting its biological function (Errasti-Murugarren et al., 2008, 2010; Cano-Soldado et al., 2012; Cano-Soldado and PastorAnglada, 2012). Genetic variability of the SLC28 genes has recently been addressed also in the context of ribavirin-based therapies in patients infected with the HCV. The analysis of SLC28A2, SLC28A3, SLC29A1, and SLC29A2 variants in a cohort of 169 patients cronically infected with HCV did not show any significant 
correlation with response to treatment. However, the SLC28A3 haplotype rs10868138G/rs56350726T was associated with protection against ribavirin-induced hemolytic anemia (Doehring et al., 2011), a finding which may be difficult to interpret as long as hENT1 is the major NT in erythrocytes. Moreover, the SLC28A3 rs56350726T variant has also been associated with SVR in a cohort of 216 patients. Some of these polymorphisms might probably affect ribavirin pharmacokinetics, as for the SLC28A2 rs11854484 variant, which was linked in the same study to high plasma ribavirin levels during combined PegIFN- $\alpha$ /ribavirin treatment (Rau et al., 2013). The same SLC28A2 variant was previously significantly associated with SVR (D'Avolio et al., 2012). Interestingly, the SCL28A2 gene product, hCNT2, has recently been shown to be a ribavirin transporter that is regulated by INF- $\alpha$ (PinillaMacua et al., 2014). Notwithstanding, considering the impact of ribavirin transporters in the clinical outcome there are limited data relative to the expression of these transporters and their polymorphisms.

\section{NTs AS DRUG TARGETS}

Nucleotides and nucleosides can be supplied by either salvage or by de novo synthesis from smaller precursors. NTs perform a crucial role in maintaining nucleoside homeostasis under physiological conditions through provision of nucleosides and nucleobases derived from the diet or produced by tissues such as liver. In this sense, as mentioned above NTs show less functional diversity than other transporter proteins and it has been suggested, as for hCNT3 as a paradigm within this family, that any change can critically compromise "fitness" in humans (Badagnani et al., 2005). This would be consistent with low evolutionary-related heterogeneity and, at least up to now, no genetic-based diseases associated with this gene family.

\section{MORE THAN TRANSPORTERS}

For years the study of these membrane proteins in the context of anticancer therapy has focused on the role these proteins might play in drug efficacy and safety. Notwithstanding, cancer represents an important pathophysiological condition that requires abnormally high levels of nucleoside influx to support higher amounts of DNA synthesis associated with the disease. Most cells express several NT-encoding genes, thereby anticipating some sort of apparent functional redundancy when analyzing transporter profiles, particularly considering that transporters often show overlapping or even identical selectivity profiles. Indeed, hCNT expression is commonly associated with fully differentiated cell types (Molina-Arcas et al., 2009; Pastor-Anglada et al., 2009; Cano-Soldado and Pastor-Anglada, 2012; Molina-Arcas and Pastor-Anglada, 2013) and oncogenesis often results in hCNT down-regulation, particularly in hCNT1 (Farre et al., 2004; Zollner et al., 2005; Lane et al., 2010; Bhutia et al., 2011; Martinez-Becerra et al., 2012; Mohelnikova-Duchonova et al., 2013; Table 4). However, the evidence of hCNT1 loss during oncogenesis needs further investigation, because almost all the studies performed so far focused exclusively on hCNT1-related mRNA levels. We have recently demonstrated that restoration of hCNT1 function in pancreatic adenocarcinoma cell lines is able to induce cell cycle arrest, increase cell death by a non-apoptotic mechanism, trigger changes in some intracellular signaling cascades and inhibit cell migration (Perez-Torras et al., 2013). More importantly, all these events can also be induced when expressing a mutated hCNT1 protein that localizes to the plasma membrane but lacks the ability to translocate substrates. Remarkably, hCNT1 protein restoration can also inhibit tumor growth in a mouse model of pancreatic adenocarcinoma (Perez-Torras et al., 2013). These observations would argue in favor of hCNT1 being a transceptor protein. This new concept within the field comes from seminal studies both in mammalian cells and yeast: a transporter that in a substrate translocation-dependent or -independent manner is able to modulate cell functions, behaving as a signalinginducer molecule or a receptor itself. Several examples of SLC membrane transporters with these additional regulatory roles have recently been reported in the literature (Lacoste etal., 2012; Coothankandaswamy et al., 2013; Perez-Torras et al., 2013; Tanaka et al., 2014).

The possibility of hCNT proteins behaving as putative transceptors might also apply to the other two members of the

Table 4 | NTs expression in tumor tissue.

\begin{tabular}{lllllll}
\hline Transporter & Tumor & Assay & $\boldsymbol{n}=$ & Expression & $\begin{array}{l}\text { Compared vs. healthy } \\
\text { tissue }\end{array}$ & Reference \\
\hline hCNT1 & Breast & IHQ & & Decreased & Yes & Lane etal. (2010) \\
hCNT1 & Pancreas & qRT-PCR, WB & 5 & Decreased & Yes & Bhutia etal. (2011) \\
hCNT1 & Ovary & IHQ & 90 & Decreased & No & Farre etal. (2004) \\
hCNT1 & Endometrium & IHQ & 79 & Decreased & No & Farre etal. (2004) \\
hCNT1 & Uterine cervix & IHQ & 118 & Decreased & No & Farre et al. (2004) \\
hCNT1 & Pancreas & qRT-PCR & 32 & Decreased & Yes & Mohelnikova-Duchonova etal. (2013) \\
hCNT1 & Hepatocarcinoma & qRT-PCR & 10 & Decreased & Yes & Zollner etal. (2005) \\
hCNT1 & Bladder & qRT-PCR & 12 & Decreased & No & Mey etal. (2006) \\
hCNT3 & Pancreas & qRT-PCR & 32 & Decreased & Yes & Mohelnikova-Duchonova etal. (2013) \\
hENT1 & Breast & IHO & & Decreased & Yes & Lane etal. (2010) \\
hENT1 & Pancreas & qRT-PCR & 32 & Decreased & Yes & Mohelnikova-Duchonova etal. (2013)
\end{tabular}


SLC28 gene family, hCNT2 and hCNT3. In contrast to hCNT1, both are high affinity adenosine transporters likely to modulate extracellular adenosine levels and, consequently, purinergic signaling. CNT2 was shown to be under the control of A1 adenosine receptors in hepatocytes by a mechanism which is dependent upon ATP-sensitive potassium channels and glucose availability (Duflot et al., 2004; Medina-Pulido et al., 2013). A similar receptor-transporter crosstalk has recently been reported for CNT2 in neurons (Medina-Pulido et al., 2013), being CNT2 expression down-regulated in the rat brain by sleep deprivation and experimental ictus (Guillen-Gomez et al., 2004; MedinaPulido et al., 2013). Moreover, adenosine taken up by CNT2 is responsible for AMP-dependent protein kinase (AMPK) activation in epithelial and neuronal models (Aymerich et al., 2006; MedinaPulido et al., 2013). As for CNT1, CNT2 expression appears to be characteristic of differentiated hepatocytes (del Santo et al., 1998, 2001; Dragan et al., 2000) being regulated by glucocorticoids and hepatocyte-specific transcription factors (Valdes et al., 2006; Fernandez-Veledo et al., 2007). On the other hand CNT3, which is not expressed in normal hepatocytes but shows broad expression in other epithelial tissues, such as colon and biliary epithelia, also appears to be a major player in regulating extracellular adenosine levels. In fact, CNT3 is under purinergic control via A2a adenosine receptors in cholangiocytes, thereby contributing to end up the initially driven purinergic control of bile flow started by ATP secretion into the bile (Godoy et al., 2014). This evidence suggest that selected NT proteins can indeed be part of the purinome, the molecular network of nucleoside and nucleotide receptors (P1 and P2), enzymes, and transporters responsible for purinergic regulation of cell functions (Volonte and D'Ambrosi, 2009). As long as some of the membrane proteins within the purinome, and other drug transporters as well, might eventually exert physiological effects other than the mere uptake or release of drugs, it can be anticipated that clinical implications of the changes in the transportome associated with the progression of disease will have to be evaluated from different perspectives and are likely to become suitable biomarkers and even drug targets.

\section{FUTURE PERSPECTIVES}

Academic research focused on human NT proteins has established so far the basis for anticipating a probable role of these membrane proteins as biomarkers of diagnosis and prognosis. One major bottleneck in translational research within this field is the lack of suitable tools. Highly reliable antibodies are needed for both immunohistochemistry and flow cytometry, although quantitative proteomics can also prove to be suitable for biomarker analysis. This would enable more comprehensive, well structured, prospective clinical studies. The determination of NT protein expression during oncogenesis and the likely relationship between changes in the NT profile and stages of tumor progression would make these biomarkers very robust, although this progress is highly dependent upon the availability of well characterized clinical specimens. A major breakthrough within the field might come from the elucidation of NT interactomics, aiming at linking NTs with other cellular events that would help in the understanding of the biological basis of their use as biomarkers.

\section{ACKNOWLEDGMENTS}

The authors would like to acknowledge past and present members of the MPET laboratory as well as the agencies which have funded MPET research, in particular projects SAF2011-23660 and IPT-2012-0673-010000 (MINECO, Spain). MPET is a member of the Oncology Program of CIBER EHD. CIBER is an initiative of Instituto de Salud Carlos III (Spain).

\section{REFERENCES}

Arimany-Nardi, C., Errasti-Murugarren, E., Minuesa, G., Martinez-Picado, J., Gorboulev, V., Koepsell, H., et al. (2014). Nucleoside transporters and human organic cation transporter 1 determine the cellular handling of DNAmethyltransferase inhibitors. Br. J. Pharmacol. 171, 3868-3880. doi: 10.1111/ bph. 12748

Avitan-Hersh, E., Mandel, H., Indelman, M., Bar-Joseph, G., Zlotogorski, A., and Bergman, R. (2011). A case of $\mathrm{H}$ syndrome showing immunophenotye similarities to Rosai-Dorfman disease. Am. J. Dermatopathol. 33, 47-51. doi: 10.1097/DAD.0b013e3181ee547c

Aymerich, I., Foufelle, F., Ferre, P., Casado, F. J., and Pastor-Anglada, M. (2006). Extracellular adenosine activates AMP-dependent protein kinase (AMPK). J. Cell Sci. 119, 1612-1621. doi: 10.1242/jcs.02865

Badagnani, I., Chan, W., Castro, R. A., Brett, C. M., Huang, C. C., Stryke, D., et al. (2005). Functional analysis of genetic variants in the human concentrative nucleoside transporter 3 (CNT3; SLC28A3). Pharmacogenomics J. 5, 157-165. doi: 10.1038/sj.tpj.6500303

Baldwin, S. A., Beal, P. R., Yao, S. Y., King, A. E., Cass, C. E., and Young, J. D. (2004). The equilibrative nucleoside transporter family, SLC29. Pflugers Arch. 447, 735-743. doi: 10.1007/s00424-003-1103-2

Baldwin, S. A., Yao, S. Y., Hyde, R. J., Ng, A. M., Foppolo, S., Barnes, K., et al. (2005). Functional characterization of novel human and mouse equilibrative nucleoside transporters (hENT3 and mENT3) located in intracellular membranes. J. Biol. Chem. 280, 15880-15887. doi: 10.1074/jbc.M414337200

Bar, F., Sina, C., and Fellermann, K. (2013). Thiopurines in inflammatory bowel disease revisited. World J. Gastroenterol. 19, 1699-1706. doi: 10.3748/wjg.v19.i11.1699

Barnes, K., Dobrzynski, H., Foppolo, S., Beal, P. R., Ismat, F., Scullion, E. R., et al. (2006). Distribution and functional characterization of equilibrative nucleoside transporter-4, a novel cardiac adenosine transporter activated at acidic pH. Circ. Res. 99, 510-519. doi: 10.1161/01.RES.0000238359.18495.42

Bhutia, Y. D., Hung, S. W., Patel, B., Lovin, D., and Govindarajan, R. (2011). CNT1 expression influences proliferation and chemosensitivity in drug-resistant pancreatic cancer cells. Cancer Res. 71, 1825-1835. doi: 10.1158/0008-5472.CAN10-2736

Bolze, A., Abhyankar, A., Grant, A. V., Patel, B., Yadav, R., Byun, M., et al. (2012). A mild form of SLC29A3 disorder: a frameshift deletion leads to the paradoxical translation of an otherwise noncoding mRNA splice variant. PLoS ONE 7:e29708. doi: 10.1371/journal.pone.0029708

Borbath, I., Verbrugghe, L., Lai, R., Gigot, J. F., Humblet, Y., Piessevaux, H., et al. (2012). Human equilibrative nucleoside transporter 1 (hENT1) expression is a potential predictive tool for response to gemcitabine in patients with advanced cholangiocarcinoma. Eur. J. Cancer 48, 990-996. doi: 10.1016/j.ejca.2011.11.006

Burckhardt, G. (2012). Drug transport by organic anion transporters (OATs). Pharmacol. Ther. 136, 106-130. doi: 10.1016/j.pharmthera.2012. 07.010

Cano-Soldado, P., Gorraitz, E., Errasti-Murugarren, E., Casado, F. J., Lostao, M. P., and Pastor-Anglada, M. (2012). Functional analysis of the human concentrative nucleoside transporter-1 variant hCNT1S546P provides insight into the sodium-binding pocket. Am. J. Physiol. Cell Physiol. 302, C257-C266. doi: 10.1152/ajpcell.00198.2011

Cano-Soldado, P., Lorrayoz, I. M., Molina-Arcas, M., Casado, F. J., Martinez-Picado, J., Lostao, M. P., et al. (2004). Interaction of nucleoside inhibitors of HIV-1 reverse transcriptase with the concentrative nucleoside transporter-1 (SLC28A1). Antivir. Ther. 9, 993-1002.

Cano-Soldado, P., and Pastor-Anglada, M. (2012). Transporters that translocate nucleosides and structural similar drugs: structural requirements for substrate recognition. Med. Res. Rev. 32, 428-457. doi: 10.1002/ med. 20221 
Cheng, Y., Vapurcuyan, A., Shahidullah, M., Aleksunes, L. M., and Pelis, R. M. (2012). Expression of organic anion transporter 2 in the human kidney and its potential role in the tubular secretion of guanine-containing antiviral drugs. Drug. Metab. Dispos. 40, 617-624. doi: 10.1124/dmd.111.042036

Cihlar, T., Ho, E. S., Lin, D. C., and Mulato, A. S. (2001). Human renal organic anion transporter 1 (hOAT1) and its role in the nephrotoxicity of antiviral nucleotide analogs. Nucleosides Nucleotides Nucleic Acids 20, 641-648. doi: 10.1081/NCN100002341

Cihlar, T., Lin, D. C., Pritchard, J. B., Fuller, M. D., Mendel, D. B., and Sweet, D. H. (1999). The antiviral nucleotide analogs cidofovir and adefovir are novel substrates for human and rat renal organic anion transporter 1. Mol. Pharmacol. 56, 570-580. doi: 10.1124/mol.56.3.570

Clarke, M. L., Damaraju, V. L., Zhang, J., Mowles, D., Tackaberry, T., Lang, T., et al. (2006). The role of human nucleoside transporters in cellular uptake of 4'-thio-beta-D-arabinofuranosylcytosine and beta-D-arabinosylcytosine. Mol. Pharmacol. 70, 303-310. doi: 10.1124/mol.105.021543

Cliffe, S. T., Kramer, J. M., Hussain, K., Robben, J. H., de Jong, E. K., de Brouwer, A. P., et al. (2009). SLC29A3 gene is mutated in pigmented hypertrichosis with insulindependent diabetes mellitus syndrome and interacts with the insulin signaling pathway. Hum. Mol. Genet. 18, 2257-2265. doi: 10.1093/hmg/ddp161

Coothankandaswamy, V., Elangovan, S., Singh, N., Prasad, P. D., Thangaraju, M., and Ganapathy, V. (2013). The plasma membrane transporter SLC5A8 suppresses tumour progression through depletion of survivin without involving its transport function. Biochem. J. 450, 169-178. doi: 10.1042/BJ20121248

D’Avolio, A., Ciancio, A., Siccardi, M., Smedile, A., Simiele, M., Cusato, J. et al. (2012). Negative predictive value of IL28B, SLC28A2, and CYP27B1 SNPs and low RBV plasma exposure for therapeutic response to PEG/IFNRBV treatment. Ther. Drug Monit. 34, 722-728. doi: 10.1097/FTD.0b013e31 $8272 \mathrm{e} 55 \mathrm{a}$

Damaraju, V. L., Mowles, D., Yao, S., Ng, A., Young, J. D., Cass, C. E., et al. (2012). Role of human nucleoside transporters in the uptake and cytotoxicity of azacitidine and decitabine. Nucleosides Nucleotides Nucleic Acids 31, 236-255. doi: $10.1080 / 15257770.2011 .652330$

De Clercq, E., and Holy, A. (2005). Acyclic nucleoside phosphonates: a key class of antiviral drugs. Nat. Rev. Drug Discov. 4, 928-940. doi: 10.1038/nrd1877

del Santo, B., Tarafa, G., Felipe, A., Casado, F. J., and Pastor-Anglada, M. (2001). Developmental regulation of the concentrative nucleoside transporters CNT1 and CNT2 in rat liver. J. Hepatol. 34, 873-880. doi: 10.1016/S0168-8278(01)00036-8

del Santo, B., Valdes, R., Mata, J., Felipe, A., Casado, F. J., and Pastor-Anglada, M. (1998). Differential expression and regulation of nucleoside transport systems in rat liver parenchymal and hepatoma cells. Hepatology 28, 1504-1511. doi: 10.1002/hep.510280609

Doehring, A., Hofmann, W. P., Schlecker, C., Zeuzem, S., Sarrazin, C., Berg, T., et al. (2011). Role of nucleoside transporters SLC28A2/3 and SLC29A1/2 genetics in ribavirin therapy: protection against anemia in patients with chronic hepatitis $\mathrm{C}$. Pharmacogenet. Genomics 21, 289-296. doi: 10.1097/FPC.0b013e32834412e7

Dragan, Y., Valdes, R., Gomez-Angelats, M., Felipe, A., Javier Casado, F., Pitot, H., et al. (2000). Selective loss of nucleoside carrier expression in rat hepatocarcinomas. Hepatology 32, 239-246. doi: 10.1053/jhep.2000.9546

Duflot, S., Riera, B., Fernandez-Veledo, S., Casado, V., Norman, R. I., Casado, F. J., et al. (2004). ATP-sensitive $\mathrm{K}(+)$ channels regulate the concentrative adenosine transporter CNT2 following activation by A(1) adenosine receptors. Mol. Cell. Biol. 24, 2710-2719. doi: 10.1128/MCB.24.7.2710-2719.2004

Elion, G. B. (1989). Nobel lecture in physiology or medicine-1988. The purine path to chemotherapy. In Vitro Cell. Dev. Biol. 25, 321-330. doi: 10.1007/ BF02624593

Endo, Y., Obata, T., Murata, D., Ito, M., Sakamoto, K., Fukushima, M., et al. (2007) Cellular localization and functional characterization of the equilibrative nucleoside transporters of antitumor nucleosides. Cancer Sci. 98, 1633-1637. doi: 10.1111/j.1349-7006.2007.00581.x

Errasti-Murugarren, E., Cano-Soldado, P., Pastor-Anglada, M., and Casado, F. J. (2008). Functional characterization of a nucleoside-derived drug transporter variant (hCNT3C602R) showing altered sodium-binding capacity. Mol. Pharmacol. 73, 379-386. doi: 10.1124/mol.107.041848

Errasti-Murugarren, E., Molina-Arcas, M., Casado, F. J., and Pastor-Anglada, M. (2010). The human concentrative nucleoside transporter-3 C602R variant shows impaired sorting to lipid rafts and altered specificity for nucleoside-derived drugs. Mol. Pharmacol. 78, 157-165. doi: 10.1124/mol.110.063552
Errasti-Murugarren, E., and Pastor-Anglada, M. (2010). Drug transporter pharmacogenetics in nucleoside-based therapies. Pharmacogenomics 11, 809-841. doi: $10.2217 /$ pgs. 10.70

Errasti-Murugarren, E., Pastor-Anglada, M., and Casado, F. J. (2007). Role of CNT3 in the transepithelial flux of nucleosides and nucleoside-derived drugs. J. Physiol. 582, 1249-1260. doi: 10.1113/jphysiol.2007.130138

Farre, X., Guillen-Gomez, E., Sanchez, L., Hardisson, D., Plaza, Y., Lloberas, J., et al. (2004). Expression of the nucleoside-derived drug transporters hCNT1, hENT1 and hENT2 in gynecologic tumors. Int. J. Cancer 112, 959-966. doi: 10.1002/ijc. 20524

Farrell, J. J., Elsaleh, H., Garcia, M., Lai, R., Ammar, A., Regine, W. F., et al. (2009). Human equilibrative nucleoside transporter 1 levels predict response to gemcitabine in patients with pancreatic cancer. Gastroenterology 136, 187-195. doi: 10.1053/j.gastro.2008.09.067

Fernandez-Veledo, S., Jover, R., Casado, F. J., Gomez-Lechon, M. J., and PastorAnglada, M. (2007). Transcription factors involved in the expression of SLC28 genes in human liver parenchymal cells. Biochem. Biophys. Res. Commun. 353, 381-388. doi: 10.1016/j.bbrc.2006.12.021

Fisher, S. B., Fisher, K. E., Patel, S. H., Lim, M. G., Kooby, D. A., El-Rayes, B. F., et al. (2013a). Excision repair cross-complementing gene-1, ribonucleotide reductase subunit $\mathrm{M} 1$, ribonucleotide reductase subunit $\mathrm{M} 2$, and human equilibrative nucleoside transporter-1 expression and prognostic value in biliary tract malignancy. Cancer 119, 454-462. doi: 10.1002/cncr.27739

Fisher, S. B., Patel, S. H., Bagci, P., Kooby, D. A., El-Rayes, B. F., Staley, C. A., et al. (2013b). An analysis of human equilibrative nucleoside transporter-1, ribonucleoside reductase subunit M1, ribonucleoside reductase subunit M2, and excision repair cross-complementing gene- 1 expression in patients with resected pancreas adenocarcinoma: implications for adjuvant treatment. Cancer 119, 445-453. doi: $10.1002 / \mathrm{cncr} .27619$

Fotoohi, A. K., Lindqvist, M., Peterson, C., and Albertioni, F. (2006). Involvement of the concentrative nucleoside transporter 3 and equilibrative nucleoside transporter 2 in the resistance of T-lymphoblastic cell lines to thiopurines. Biochem. Biophys. Res. Commun. 343, 208-215. doi: 10.1016/j.bbrc.2006.02.134

Frei, P., Biedermann, L., Nielsen, O. H., and Rogler, G. (2013). Use of thiopurines in inflammatory bowel disease. World J. Gastroenterol. 19, 1040-1048. doi: 10.3748/wjg.v19.i7.1040

Friedman, A. B., Sparrow, M. P., and Gibson, P. R. (2014). The role of thiopurine metabolites in inflammatory bowel disease and rheumatological disorders. Int. J. Rheum. Dis. 17, 132-141. doi: 10.1111/1756-185X.12204

Fujita, H., Ohuchida, K., Mizumoto, K., Itaba, S., Ito, T., Nakata, K., et al. (2010). Gene expression levels as predictive markers of outcome in pancreatic cancer after gemcitabine-based adjuvant chemotherapy. Neoplasia 12, 807-817.

Fukuchi, Y., Furihata, T., Hashizume, M., Iikura, M., and Chiba, K. (2010). Characterization of ribavirin uptake systems in human hepatocytes. J. Hepatol. 52, 486-492. doi: 10.1016/j.jhep.2010.01.011

Furihata, T., Matsumoto, S., Fu, Z., Tsubota, A., Sun, Y., Kobayashi, K., et al. (2014). Different interaction profiles of direct-acting anti-hepatitis $C$ virus agents with human organic anion transporting polypeptides. Antimicrob. Agents Chemother. 58, 4555-4564. doi: 10.1128/AAC.02724-14

Ganapathy, M. E., Huang, W., Wang, H., Ganapathy, V., and Leibach, F. H. (1998). Valacyclovir: a substrate for the intestinal and renal peptide transporters PEPT1 and PEPT2. Biochem. Biophys. Res. Commun. 246, 470-475. doi: 10.1006/bbrc. 1998.8628

Giovannetti, E., Del Tacca, M., Mey, V., Funel, N., Nannizzi, S., Ricci, S., et al. (2006). Transcription analysis of human equilibrative nucleoside transporter-1 predicts survival in pancreas cancer patients treated with gemcitabine. Cancer Res. 66, 3928-3935. doi: 10.1158/0008-5472.CAN-05-4203

Gloeckner-Hofmann, K., Guillen-Gomez, E., Schmidtgen, C., Porstmann, R., Ziegler, R., Stoss, O., etal. (2006). Expression of the high-affinity fluoropyrimidine-preferring nucleoside transporter hCNT1 correlates with decreased disease-free survival in breast cancer. Oncology 70, 238-244. doi: $10.1159 / 000094541$

Godoy, V., Banales, J. M., Medina, J. F., and Pastor-Anglada, M. (2014). Functional crosstalk between the adenosine transporter CNT3 and purinergic receptors in the biliary epithelia. J. Hepatol. 61, 1337-1343. doi: 10.1016/j.jhep.2014.06.036

Gorraitz, E., Pastor-Anglada, M., and Lostao, M. P. (2010). Effects of $\mathrm{Na}^{+}$and $\mathrm{H}^{+}$on steady-state and presteady-state currents of the human concentrative nucleoside 
transporter 3 (hCNT3). Pflugers Arch. 460, 617-632. doi: 10.1007/s00424-0100846-9

Govindarajan, R., Endres, C. J., Whittington, D., LeCluyse, E., Pastor-Anglada, M., Tse, C. M., et al. (2008). Expression and hepatobiliary transport characteristics of the concentrative and equilibrative nucleoside transporters in sandwich-cultured human hepatocytes. Am. J. Physiol. Gastrointest. Liver Physiol. 295, G570-G580. doi: 10.1152/ajpgi.00542.2007

Govindarajan, R., Leung, G. P., Zhou, M., Tse, C. M., Wang, J., and Unadkat, J. D. (2009). Facilitated mitochondrial import of antiviral and anticancer nucleoside drugs by human equilibrative nucleoside transporter-3. Am. J. Physiol. Gastrointest. Liver Physiol. 296, G910-G922. doi: 10.1152/ajpgi.90672.2008

Greenhalf, W., Ghaneh, P., Neoptolemos, J. P., Palmer, D. H., Cox, T. F., Lamb, R. F., et al. (2014). Pancreatic cancer hENT1 expression and survival from gemcitabine in patients from the ESPAC-3 trial. J. Natl. Cancer Inst. 106, djt347. doi: 10.1093/jnci/djt347

Grundemann, D., Schechinger, B., Rappold, G. A., and Schomig, E. (1998). Molecular identification of the corticosterone-sensitive extraneuronal catecholamine transporter. Nat. Neurosci. 1, 349-351. doi: 10.1038/1557

Grundemann, D., and Schomig, E. (2000). Gene structures of the human nonneuronal monoamine transporters EMT and OCT2. Hum. Genet. 106, 627-635. doi: 10.1007/s004390000309

Guillen-Gomez, E., Calbet, M., Casado, J., de Lecea, L., Soriano, E., Pastor-Anglada, M., et al. (2004). Distribution of CNT2 and ENT1 transcripts in rat brain: selective decrease of CNT2 mRNA in the cerebral cortex of sleep-deprived rats. J. Neurochem. 90, 883-893. doi: 10.1111/j.1471-4159.2004.02545.x

Guillen-Gomez, E., Pinilla-Macua, I., Perez-Torras, S., Choi, D. S., Arce, Y., Ballarin, J. A., et al. (2012). New role of the human equilibrative nucleoside transporter 1 (hENT1) in epithelial-to-mesenchymal transition in renal tubular cells. J. Cell. Physiol. 227, 1521-1528. doi: 10.1002/jcp.22869

Hatanaka, T., Haramura, M., Fei, Y.-J., Miyauchi, S., Bridges, C. C., Ganapathy, P. S., et al. (2004). Transport of amino acid-based prodrugs by the $\mathrm{Na}+-$ and $\mathrm{Cl}(-)$ -coupled amino acid transporter ATB0,+ and expression of the transporter in tissues amenable for drug delivery. J. Pharmacol. Exp. Ther. 308, 1138-1147. doi: 10.1124/jpet.103.057109

Hsu, C. L., Lin, W., Seshasayee, D., Chen, Y. H., Ding, X., Lin, Z., et al. (2012). Equilibrative nucleoside transporter 3 deficiency perturbs lysosome function and macrophage homeostasis. Science 335, 89-92. doi: 10.1126/science.1213682

Hu, H., Endres, C. J., Chang, C., Umapathy, N. S., Lee, E. W., Fei, Y. J., et al. (2006). Electrophysiological characterization and modeling of the structure activity relationship of the human concentrative nucleoside transporter 3 (hCNT3). Mol. Pharmacol. 69, 1542-1553. doi: 10.1124/mol.105.018945

Huber-Ruano, I., Errasti-Murugarren, E., Godoy, V., Vera, A., Andreu, A. L., GarciaArumi, E., et al. (2012). Functional outcome of a novel SLC29A3 mutation identified in a patient with H syndrome. Biochem. Biophys. Res. Commun. 428, 532-537. doi: 10.1016/j.bbrc.2012.09.143

Huber-Ruano, I., and Pastor-Anglada, M. (2009). Transport of nucleoside analogs across the plasma membrane: a clue to understanding drug-induced cytotoxicity. Curr. Drug Metab. 10, 347-358. doi: 10.2174/138920009788499030

Jarvis, S. M., Thorn, J. A., and Glue, P. (1998). Ribavirin uptake by human erythrocytes and the involvement of nitrobenzylthioinosine-sensitive (es)nucleoside transporters. Br. J. Pharmacol. 123, 1587-1592. doi: 10.1038/sj.bjp. 0701775

Jordheim, L. P., Durantel, D., Zoulim, F., and Dumontet, C. (2013). Advances in the development of nucleoside and nucleotide analogues for cancer and viral diseases. Nat. Rev. Drug Discov. 12, 447-464. doi: 10.1038/nrd4010

Jung, N., Lehmann, C., Rubbert, A., Knispel, M., Hartmann, P., van Lunzen, J., et al. (2008). Relevance of the organic cation transporters 1 and 2 for antiretroviral drug therapy in human immunodeficiency virus infection. Drug Metab. Dispos. 36, 1616-1623. doi: 10.1124/dmd.108.020826

Kang, N., Jun, A. H., Bhutia, Y. D., Kannan, N., Unadkat, J. D., and Govindarajan, R. (2010). Human equilibrative nucleoside transporter-3 (hENT3) spectrum disorder mutations impair nucleoside transport, protein localization, and stability. J. Biol. Chem. 285, 28343-28352. doi: 10.1074/jbc.M110.109199

Kawada, N., Uehara, H., Katayama, K., Nakamura, S., Takahashi, H., Ohigashi, H., et al. (2012). Human equilibrative nucleoside transporter 1 level does not predict prognosis in pancreatic cancer patients treated with neoadjuvant chemoradiation including gemcitabine. J. Hepatobiliary Pancreat. Sci. 19, 717-722. doi: 10.1007/s00534-012-0514-x
Kim, R., Tan, A., Lai, K. K., Jiang, J., Wang, Y., Rybicki, L. A., et al. (2011). Prognostic roles of human equilibrative transporter 1 (hENT-1) and ribonucleoside reductase subunit M1 (RRM1) in resected pancreatic cancer. Cancer 117, 3126-3134. doi: 10.1002/cncr.25883

Kim, S. R., Saito, Y., Maekawa, K., Sugiyama, E., Kaniwa, N., Ueno, H., et al. (2006). Thirty novel genetic variations in the SLC29A1 gene encoding human equilibrative nucleoside transporter 1 (hENT1). Drug Metab. Pharmacokinet. 21, 248-256. doi: 10.2133/dmpk.21.248

King, K. M., Damaraju, V. L., Vickers, M. F., Yao, S. Y., Lang, T., Tackaberry, T. E., et al. (2006). A comparison of the transportability, and its role in cytotoxicity, of clofarabine, cladribine, and fludarabine by recombinant human nucleoside transporters produced in three model expression systems. Mol. Pharmacol. 69, 346-353.

Kobayashi, H., Murakami, Y., Uemura, K., Sudo, T., Hashimoto, Y., Kondo, N., et al. (2012). Human equilibrative nucleoside transporter 1 expression predicts survival of advanced cholangiocarcinoma patients treated with gemcitabine-based adjuvant chemotherapy after surgical resection. Ann. Surg. 256, 288-296. doi: 10.1097/SLA.0b013e3182536a42

Kobayashi, Y., Ohshiro, N., Sakai, R., Ohbayashi, M., Kohyama, N., and Yamamoto, T. (2005). Transport mechanism and substrate specificity of human organic anion transporter 2 (hOat2 [SLC22A7]). J. Pharm. Pharmacol. 57, 573-578.

Koehler, M. R., Wissinger, B., Gorboulev, V., Koepsell, H., and Schmid, M. (1997). The two human organic cation transporter genes SLC22A1 and SLC22A2 are located on chromosome 6q26. Cytogenet. Cell Genet. 79, 198-200. doi: $10.1159 / 000134720$

Koepsell, H. (2013). The SLC22 family with transporters of organic cations, anions and zwitterions. Mol. Aspects Med. 34, 413-435. doi: 10.1016/j.mam.2012.10.010 Koepsell, H., Schmitt, B. M., and Gorboulev, V. (2003). Organic cation transporters. Rev. Physiol. Biochem. Pharmacol. 150, 36-90. doi: 10.1007/s10254-003-0017-x

Kondo, N., Murakami, Y., Uemura, K., Sudo, T., Hashimoto, Y., Nakashima, A., et al. (2012). Combined analysis of dihydropyrimidine dehydrogenase and human equilibrative nucleoside transporter 1 expression predicts survival of pancreatic carcinoma patients treated with adjuvant gemcitabine plus S-1 chemotherapy after surgical resection. Ann. Surg. Oncol. 19(Suppl. 3), S646-S655. doi: 10.1245/s10434-011-2140-2

Lacoste, C., Herve, J., Bou Nader, M., Dos Santos, A., Moniaux, N., Valogne, Y., et al. (2012). Iodide transporter NIS regulates cancer cell motility and invasiveness by interacting with the Rho guanine nucleotide exchange factor LARG. Cancer Res. 72, 5505-5515. doi: 10.1158/0008-5472.CAN-12-0516

Lai, Y., Bakken, A. H., and Unadkat, J. D. (2002). Simultaneous expression of hCNT1-CFP and hENT1-YFP in Madin-Darby canine kidney cells. Localization and vectorial transport studies. J. Biol. Chem. 277, 37711-37717. doi: 10.1074/jbc.M204986200

Lane, J., Martin, T. A., McGuigan, C., Mason, M. D., and Jiang, W. G. (2010). The differential expression of hCNT1 and hENT1 i n breast cancer and the possible impact on breast cancer therapy. J. Exp. Ther. Oncol. 8, 203-210.

Lang, T. T., Selner, M., Young, J. D., and Cass, C. E. (2001). Acquisition of human concentrative nucleoside transporter 2 (hcnt2) activity by gene transfer confers sensitivity to fluoropyrimidine nucleosides in drug-resistant leukemia cells. Mol. Pharmacol. 60, 1143-1152.

Lee, Y., Koay, E. J., Zhang, W., Qin, L., Kirui, D. K., Hussain, F., et al. (2014). Human equilibrative nucleoside transporter-1 knockdown tunes cellular mechanics through epithelial-mesenchymal transition in pancreatic cancer cells. PLoS ONE 9:e107973. doi: 10.1371/journal.pone.0107973

Mackey, J. R., Yao, S. Y., Smith, K. M., Karpinski, E., Baldwin, S. A., Cass, C. E., et al. (1999). Gemcitabine transport in xenopus oocytes expressing recombinant plasma membrane mammalian nucleoside transporters. J. Natl. Cancer Inst. 91, 1876-1881. doi: 10.1093/jnci/91.21.1876

Mangravite, L. M., Lipschutz, J. H., Mostov, K. E., and Giacomini, K. M. (2001). Localization of GFP-tagged concentrative nucleoside transporters in a renal polarized epithelial cell line. Am. J. Physiol. Renal Physiol. 280, F879-F885.

Mangravite, L. M., Xiao, G., and Giacomini, K. M. (2003). Localization of human equilibrative nucleoside transporters, hENT1 and hENT2, in renal epithelial cells. Am. J. Physiol. Renal Physiol. 284, F902-F910. doi: 10.1152/ajprenal. 00215.2002

Marce, S., Molina-Arcas, M., Villamor, N., Casado, F. J., Campo, E., Pastor-Anglada, M., et al. (2006). Expression of human equilibrative nucleoside transporter 1 
(hENT1) and its correlation with gemcitabine uptake and cytotoxicity in mantle cell lymphoma. Haematologica 91, 895-902.

Maréchal, R., Bachet, J. B., Mackey, J. R., Dalban, C., Demetter, P., Graham, K., et al. (2012). Levels of gemcitabine transport and metabolism proteins predict survival times of patients treated with gemcitabine for pancreatic adenocarcinoma. Gastroenterology 143, 664-674.e1-e6. doi: 10.1053/j.gastro.2012.06.006

Maréchal, R., Mackey, J. R., Lai, R., Demetter, P., Peeters, M., Polus, M., et al (2009). Human equilibrative nucleoside transporter 1 and human concentrative nucleoside transporter 3 predict survival after adjuvant gemcitabine therapy in resected pancreatic adenocarcinoma. Clin. Cancer Res. 15, 2913-2919. doi: 10.1158/1078-0432.CCR-08-2080

Martinez-Becerra, P., Vaquero, J., Romero, M. R., Lozano, E., Anadon, C., Macias, R. I., et al. (2012). No correlation between the expression of FXR and genes involved in multidrug resistance phenotype of primary liver tumors. Mol. Pharm. 9, 1693-1704. doi: 10.1021/mp300028a

Mata, J. F., García-Manteiga, J. M., Lostao, M. P., Fernández-Veledo, S., GuillénGómez, E., Larrayoz, I. M., etal. (2001). Role of the human concentrative nucleoside transporter (hCNT1) in the cytotoxic action of 5[Prime]-deoxy-5fluorouridine, an active intermediate metabolite of capecitabine, a novel oral anticancer drug. Mol. Pharmacol. 59, 1542-1548. doi: 10.1124/mol.59.6.1542

Matsumura, N., Nakamura, Y., Kohjimoto, Y., Inagaki, T., Nanpo, Y., Yasuoka, H., et al. (2011). The prognostic significance of human equilibrative nucleoside transporter 1 expression in patients with metastatic bladder cancer treated with gemcitabine-cisplatin-based combination chemotherapy. BJU Int. 108, E110E116. doi: 10.1111/j.1464-410X.2010.09932.x

Medina-Pulido, L., Molina-Arcas, M., Justicia, C., Soriano, E., Burgaya, F., Planas, A. M., et al. (2013). Hypoxia and P1 receptor activation regulate the high-affinity concentrative adenosine transporter CNT2 in differentiated neuronal PC12 cells. Biochem. J. 454, 437-445. doi: 10.1042/BJ20130231

Mey, V., Giovannetti, E., De Braud, F., Nannizzi, S., Curigliano, G., Verweij, F., etal. (2006). In vitro synergistic cytotoxicity of gemcitabine and pemetrexed and pharmacogenetic evaluation of response to gemcitabine in bladder cancer patients. Br. J. Cancer 95, 289-297. doi: 10.1038/sj.bjc. 6603242

Minuesa, G., Huber-Ruano, I., Pastor-Anglada, M., Koepsell, H., Clotet, B., and Martinez-Picado, J. (2011). Drug uptake transporters in antiretroviral therapy. Pharmacol. Ther. 132, 268-279. doi: 10.1016/j.pharmthera.2011.06.007

Minuesa, G., Purcet, S., Erkizia, I., Molina-Arcas, M., Bofill, M., Izquierdo-Useros, N., et al. (2008). Expression and functionality of anti-human immunodeficiency virus and anticancer drug uptake transporters in immune cells. J. Pharmacol. Exp. Ther. 324, 558-567. doi: 10.1124/jpet.107.131482

Minuesa, G., Volk, C., Molina-Arcas, M., Gorboulev, V., Erkizia, I., Arndt, P., et al. (2009). Transport of lamivudine [(-)-beta-L-2',3'-dideoxy-3'-thiacytidine] and high-affinity interaction of nucleoside reverse transcriptase inhibitors with human organic cation transporters 1, 2, and 3. J. Pharmacol. Exp. Ther. 329, 252-261. doi: 10.1124/jpet.108.146225

Mohelnikova-Duchonova, B., Brynychova, V., Hlavac, V., Kocik, M., Oliverius, M., Hlavsa, J., et al. (2013). The association between the expression of solute carrier transporters and the prognosis of pancreatic cancer. Cancer Chemother. Pharmacol. 72, 669-682. doi: 10.1007/s00280-013-2246-2

Molho-Pessach, V., Lerer, I., Abeliovich, D., Agha, Z., Abu Libdeh, A., Broshtilova, $\mathrm{V}$, et al. (2008). The $\mathrm{H}$ syndrome is caused by mutations in the nucleoside transporter hENT3. Am. J. Hum. Genet. 83, 529-534. doi: 10.1016/j.ajhg.2008. 09.013

Molho-Pessach, V., Ramot, Y., Camille, F., Doviner, V., Babay, S., Luis, S. J., et al. (2014). H syndrome: the first 79 patients. J. Am. Acad. Dermatol. 70, 80-88. doi: 10.1016/j.jaad.2013.09.019

Molina-Arcas, M., Bellosillo, B., Casado, F. J., Montserrat, E., Gil, J., Colomer, D., et al. (2003). Fludarabine uptake mechanisms in B-cell chronic lymphocytic leukemia. Blood 101, 2328-2334. doi: 10.1182/blood-200207-2236

Molina-Arcas, M., Casado, F. J., and Pastor-Anglada, M. (2009). Nucleoside transporter proteins. Curr. Vasc. Pharmacol. 7, 426-434. doi: 10.2174/157016109789043892

Molina-Arcas, M., Marce, S., Villamor, N., Huber-Ruano, I., Casado, F. J., Bellosillo, B., et al. (2005). Equilibrative nucleoside transporter-2 (hENT2) protein expression correlates with ex vivo sensitivity to fludarabine in chronic lymphocytic leukemia (CLL) cells. Leukemia 19, 64-68.
Molina-Arcas, M., Moreno-Bueno, G., Cano-Soldado, P., Hernandez-Vargas, H., Casado, F. J., Palacios, J., etal. (2006). Human equilibrative nucleoside transporter-1 (hENT1) is required for the transcriptomic response of the nucleoside-derived drug $5^{\prime}$-DFUR in breast cancer MCF7 cells. Biochem. Pharmacol. 72, 1646-1656. doi: 10.1016/j.bcp.2006.07.036

Molina-Arcas, M., and Pastor-Anglada, M. (2013). "Nucleoside transporters (SLC28 and SLC29) family," in Pharmacogenomics of Drug Transporters, eds T. Ishikawa, R. B. Kim, J. König (Hoboken, NJ: John Wiley \& Sons, Inc), 243-270. doi: 10.1002/9781118353240.ch11

Morgan, N. V., Morris, M. R., Cangul, H., Gleeson, D., Straatman-Iwanowska, A., Davies, N., et al. (2010). Mutations in SLC29A3, encoding an equilibrative nucleoside transporter ENT3, cause a familial histiocytosis syndrome (Faisalabad histiocytosis) and familial Rosai-Dorfman disease. PLoS Genet. 6:e1000833. doi: 10.1371/journal.pgen.1000833

Mori, R., Ishikawa, T., Ichikawa, Y., Taniguchi, K., Matsuyama, R., Ueda, M., et al. (2007). Human equilibrative nucleoside transporter 1 is associated with the chemosensitivity of gemcitabine in human pancreatic adenocarcinoma and biliary tract carcinoma cells. Oncol. Rep. 17, 1201-1205.

Morinaga, S., Nakamura, Y., Watanabe, T., Mikayama, H., Tamagawa, H., Yamamoto, N., et al. (2012). Immunohistochemical analysis of human equilibrative nucleoside transporter-1 (hENT1) predicts survival in resected pancreatic cancer patients treated with adjuvant gemcitabine monotherapy. Ann. Surg. Oncol. 19(Suppl. 3), S558-S564. doi: 10.1245/s10434-011-2054-Z

Muller, J., Lips, K. S., Metzner, L., Neubert, R. H., Koepsell, H., and Brandsch, M. (2005). Drug specificity and intestinal membrane localization of human organic cation transporters (OCT). Biochem. Pharmacol. 70, 1851-1860. doi: 10.1016/j.bcp.2005.09.011

Murata, A., Amano, R., Yamada, N., Kimura, K., Yashiro, M., Nakata, B., et al. (2013). Prognostic predictive values of gemcitabine sensitivity-related gene products for unresectable or recurrent biliary tract cancer treated with gemcitabine alone. World J. Surg. Oncol. 11, 117. doi: 10.1186/1477-7819-11-117

Murata, Y., Hamada, T., Kishiwada, M., Ohsawa, I., Mizuno, S., Usui, M., et al. (2012). Human equilibrative nucleoside transporter 1 expression is a strong independent prognostic factor in UICC T3-T4 pancreatic cancer patients treated with preoperative gemcitabine-based chemoradiotherapy. J. Hepatobiliary Pancreat. Sci. 19, 413-425. doi: 10.1007/s00534-011-0440-3

Myers, S. N., Goyal, R. K., Roy, J. D., Fairfull, L. D., Wilson, J. W., and Ferrell, R. E. (2006). Functional single nucleotide polymorphism haplotypes in the human equilibrative nucleoside transporter 1. Pharmacogenet. Genomics 16, 315-320. doi: 10.1097/01.fpc.0000189804.41962.15

Nakagawa, N., Murakami, Y., Uemura, K., Sudo, T., Hashimoto, Y., Kondo, N., et al. (2013). Combined analysis of intratumoral human equilibrative nucleoside transporter 1 (hENT1) and ribonucleotide reductase regulatory subunit M1 (RRM1) expression is a powerful predictor of survival in patients with pancreatic carcinoma treated with adjuvant gemcitabine-based chemotherapy after operative resection. Surgery 153, 565-575. doi: 10.1016/j.surg.2012.10.010

Nies, A. T., Koepsell, H., Winter, S., Burk, O., Klein, K., Kerb, R., et al. (2009). Expression of organic cation transporters OCT1 (SLC22A1) and OCT3 (SLC22A3) is affected by genetic factors and cholestasis in human liver. Hepatology 50, 1227-1240. doi: 10.1002/hep.23103

Oguri, T., Achiwa, H., Muramatsu, H., Ozasa, H., Sato, S., Shimizu, S., et al. (2007). The absence of human equilibrative nucleoside transporter 1 expression predicts nonresponse to gemcitabine-containing chemotherapy in non-small cell lung cancer. Cancer Lett. 256, 112-119. doi: 10.1016/j.canlet.2007. 06.012

Okazaki, T., Javle, M., Tanaka, M., Abbruzzese, J. L., and Li, D. (2010). Single nucleotide polymorphisms of gemcitabine metabolic genes and pancreatic cancer survival and drug toxicity. Clin. Cancer Res. 16, 320-329. doi: 10.1158/10780432.CCR-09-1555

Ormanns, S., Heinemann, V., Raponi, M., Isaacson, J., Laubender, R. P., Haas, M., et al. (2014). Human equilibrative nucleoside transporter 1 is not predictive for gemcitabine efficacy in advanced pancreatic cancer: translational results from the AIO-PK0104 phase III study with the clone SP120 rabbit antibody. Eur. J. Cancer 50, 1891-1899. doi: 10.1016/j.ejca.2014.04.023

Osato, D. H., Huang, C. C., Kawamoto, M., Johns, S. J., Stryke, D., Wang, J., et al. (2003). Functional characterization in yeast of genetic variants in the human equilibrative nucleoside transporter, ENT1. Pharmacogenetics 13, 297-301. doi: 10.1097/00008571-200305000-00010 
Osses, N., Pearson, J. D., Yudilevich, D. L., and Jarvis, S. M. (1996). Hypoxanthine enters human vascular endothelial cells (ECV 304) via the nitrobenzylthioinosineinsensitive equilibrative nucleoside transporter. Biochem. J. 317, 843-848.

Owen, R. P., Lagpacan, L. L., Taylor, T. R., De La Cruz, M., Huang, C. C., Kawamoto, M., et al. (2006). Functional characterization and haplotype analysis of polymorphisms in the human equilibrative nucleoside transporter, ENT2. Drug Metab. Dispos. 34, 12-15. doi: 10.1124/dmd.105.006270

Parker, W. B. (2009). Enzymology of purine and pyrimidine antimetabolites used in the treatment of cancer. Chem. Rev. 109, 2880-2893. doi: 10.1021/cr900028p

Pastor-Anglada, M., Molina-Arcas, M., Cano-Soldado, P., and Casado, F. J. (2009). "Biochemistry, physiology and pharmacology of nucleoside and nucleobase transporters," in Transporters as Drugs Carriers, ed. G. C. Ecker (Weinheim: Wiley-VCH), 49-80. doi: 10.1002/9783527627424.ch2

Patil, S. D., Ngo, L. Y., Glue, P., and Unadkat, J. D. (1998). Intestinal absorption of ribavirin is preferentially mediated by the $\mathrm{Na}+$-nucleoside purine $(\mathrm{N} 1)$ transporter Pharm. Res. 15, 950-952.

Perez-Torras, S., Garcia-Manteiga, J., Mercade, E., Casado, F. J., Carbo, N., Pastor-Anglada, M., et al. (2008). Adenoviral-mediated overexpression of human equilibrative nucleoside transporter 1 (hENT1) enhances gemcitabine response in human pancreatic cancer. Biochem. Pharmacol. 76, 322-329. doi: 10.1016/j.bcp.2008.05.011

Perez-Torras, S., Vidal-Pla, A., Cano-Soldado, P., Huber-Ruano, I., Mazo, A., and Pastor-Anglada, M. (2013). Concentrative nucleoside transporter 1 (hCNT1) promotes phenotypic changes relevant to tumor biology in a translocationindependent manner. Cell Death Dis. 4:e648. doi: 10.1038/cddis.2013.173

Perrone, G., Morini, S., Santini, D., Rabitti, C., Vincenzi, B., Alloni, R., et al. (2010). Human equilibrative nucleoside transporter 1 and carcinoma of the ampulla of Vater: expression differences in tumour histotypes. Eur. J. Histochem. 54:e38. doi 10.4081/ejh.2010.e38

Pinilla-Macua, I., Fernandez-Calotti, P., Perez-Del-Pulgar, S., and PastorAnglada, M. (2014). Ribavirin uptake into human hepatocyte HHL5 cells is enhanced by interferon-alpha via up-regulation of the human concentrative nucleoside transporter (hCNT2). Mol. Pharm. 11, 3223-3230. doi: 10.1021/ mp500263p

Prasad, B., Evers, R., Gupta, A., Hop, C. E., Salphati, L., Shukla, S., et al. (2014). Interindividual variability in hepatic organic anion-transporting polypeptides and P-glycoprotein (ABCB1) protein expression: quantification by liquid chromatography tandem mass spectroscopy and influence of genotype, age, and sex. Drug Metab. Dispos. 42, 78-88. doi: 10.1124/dmd.113.053819

Prus, K. L., Averett, D. R., and Zimmerman, T. P. (1990). Transport and metabolism of 9-beta-D-arabinofuranosylguanine in a human T-lymphoblastoid cell line: nitrobenzylthioinosine-sensitive and -insensitive influx. Cancer Res. 50, 1817-1821.

Quashie, N. B., Ranford-Cartwright, L. C., and de Koning, H. P. (2010). Uptake of purines in Plasmodium falciparum-infected human erythrocytes is mostly mediated by the human equilibrative nucleoside transporter and the human facilitative nucleobase transporter. Malar. J. 9:36. doi: 10.1186/1475-2875-9-36

Rau, M., Stickel, F., Russmann, S., Manser, C. N., Becker, P. P., Weisskopf, M., et al. (2013). Impact of genetic SLC28 transporter and ITPA variants on ribavirin serum level, hemoglobin drop and therapeutic response in patients with HCV infection. J. Hepatol. 58, 669-675. doi: 10.1016/j.jhep.2012.11.027

Ritzel, M. W., Ng, A. M., Yao, S. Y., Graham, K., Loewen, S. K., Smith, K. M., et al. (2001). Recent molecular advances in studies of the concentrative $\mathrm{Na}$--dependent nucleoside transporter (CNT) family: identification and characterization of novel human and mouse proteins (hCNT3 and mCNT3) broadly selective for purine and pyrimidine nucleosides (system cib). Mol. Membr. Biol. 18, 65-72. doi: 10.1080/09687680118530

Ritzel, M. W., Yao, S. Y., Ng, A. M., Mackey, J. R., Cass, C. E., and Young, J. D. (1998). Molecular cloning, functional expression and chromosomal localization of a cDNA encoding a human Na+/nucleoside cotransporter (hCNT2) selective for purine nucleosides and uridine. Mol. Membr. Biol. 15, 203-211.

Rius, M., Stresemann, C., Keller, D., Brom, M., Schirrmacher, E., Keppler, D., et al. (2009). Human concentrative nucleoside transporter 1-mediated uptake of 5azacytidine enhances DNA demethylation. Mol. Cancer. Ther. 8, 225-231. doi: 10.1158/1535-7163.MCT-08-0743

Rizwan, A. N., and Burckhardt, G. (2007). Organic anion transporters of the SLC22 family: biopharmaceutical, physiological, and pathological roles. Pharm. Res. 24, 450-470. doi: 10.1007/s11095-006-9181-4
Rizzieri, D., Vey, N., Thomas, X., Huguet-Rigal, F., Schlenk, R. F., Krauter, J., et al. (2014). A phase II study of elacytarabine in combination with idarubicin and of human equilibrative nucleoside transporter 1 expression in patients with acute myeloid leukemia and persistent blasts after the first induction course. Leuk. Lymphoma 55, 2114-2119. doi: 10.3109/10428194.2013.867489

Sakamoto, A., Matsumaru, T., Yamamura, N., Uchida, Y., Tachikawa, M., Ohtsuki, S., et al. (2013). Quantitative expression of human drug transporter proteins in lung tissues: analysis of regional, gender, and interindividual differences by liquid chromatography-tandem mass spectrometry. J. Pharm. Sci. 102, 3395-3406. doi: 10.1002/jps.23606

Santini, D., Perrone, G., Vincenzi, B., Lai, R., Cass, C., Alloni, R., et al. (2008). Human equilibrative nucleoside transporter 1 (hENT1) protein is associated with short survival in resected ampullary cancer. Ann. Oncol. 19, 724-728. doi: 10.1093/annonc/mdm576

Santini, D., Schiavon, G., Vincenzi, B., Cass, C. E., Vasile, E., Manazza, A. D., et al. (2011). Human equilibrative nucleoside transporter 1 (hENT1) levels predict response to gemcitabine in patients with biliary tract cancer (BTC). Curr. Cancer Drug. Targets 11, 123-129. doi: 10.2174/156800911793743600

Santini, D., Vincenzi, B., Fratto, M. E., Perrone, G., Lai, R., Catalano, V., et al. (2010). Prognostic role of human equilibrative transporter 1 (hENT1) in patients with resected gastric cancer. J. Cell. Physiol. 223, 384-388. doi: 10.1002/ jcp. 22045

Smith, K. M., Ng, A. M., Yao, S. Y., Labedz, K. A., Knaus, E. E., Wiebe, L. I., et al. (2004). Electrophysiological characterization of a recombinant human $\mathrm{Na}+-$ coupled nucleoside transporter (hCNT1) produced in Xenopus oocytes. J. Physiol. 558, 807-823. doi: 10.1113/jphysiol.2004.068189

Smith, K. M., Slugoski, M. D., Cass, C. E., Baldwin, S. A., Karpinski, E., and Young, J. D. (2007). Cation coupling properties of human concentrative nucleoside transporters hCNT1, hCNT2 and hCNT3. Mol. Membr. Biol. 24, 53-64. doi: $10.1080 / 09687860600942534$

Smith, K. M., Slugoski, M. D., Loewen, S. K., Ng, A. M., Yao, S. Y., Chen, X. Z., et al. (2005). The broadly selective human $\mathrm{Na}+$ /nucleoside cotransporter (hCNT3) exhibits novel cation-coupled nucleoside transport characteristics. J. Biol. Chem. 280, 25436-25449. doi: 10.1074/jbc.M409454200

Spiegel, R., Cliffe, S. T., Buckley, M. F., Crow, Y. J., Urquhart, J., Horovitz, Y., et al. (2010). Expanding the clinical spectrum of SLC29A3 gene defects. Eur. J. Med. Genet. 53, 309-313. doi: 10.1016/j.ejmg.2010.06.012

Spratlin, J., Sangha, R., Glubrecht, D., Dabbagh, L., Young, J. D., Dumontet, C., et al. (2004). The absence of human equilibrative nucleoside transporter 1 is associated with reduced survival in patients with gemcitabine-treated pancreas adenocarcinoma. Clin. Cancer Res. 10, 6956-6961. doi: 10.1158/1078-0432.CCR04-0224

Sugawara, M., Huang, W., Fei, Y. J., Leibach, F. H., Ganapathy, V., and Ganapathy, M. E. (2000). Transport of valganciclovir, a ganciclovir prodrug, via peptide transporters PEPT1 and PEPT2. J. Pharm. Sci. 89, 781-789. doi: 10.1002/(SICI)1520-6017(200006)89:6<781::AID-JPS10>3.0.CO;2-7

Svrcek, M., Cros, J., Marechal, R., Bachet, J. B., Flejou, J. F., and Demetter, P. (2014). hENT1 testing in pancreatic ductal adenocarcinoma: a comparison between the murine and the rabbit antibodies. Histopathology. doi: 10.1111/his.12577 [Epub ahead of print].

Takeda, M., Khamdang, S., Narikawa, S., Kimura, H., Kobayashi, Y., Yamamoto, T., et al. (2002). Human organic anion transporters and human organic cation transporters mediate renal antiviral transport. J. Pharmacol. Exp. Ther. 300, 918924. doi: 10.1124/jpet.300.3.918

Tanaka, T., Doe, J. M., Horstmann, S. A., Ahmad, S., Ahmad, A., Min, S. J., et al. (2014). Neuroendocrine signaling via the serotonin transporter regulates clearance of apoptotic cells. J. Biol. Chem. 289, 10466-10475. doi: 10.1074/jbc.M113.482299

Umapathy, N. S., Ganapathy, V., and Ganapathy, M. E. (2004). Transport of amino acid esters and the amino-acid-based prodrug valganciclovir by the amino acid transporter $\operatorname{ATB}(0,+)$. Pharm. Res. 21, 1303-1310.

Uwai, Y., Ida, H., Tsuji, Y., Katsura, T., and Inui, K. (2007). Renal transport of adefovir, cidofovir, and tenofovir by SLC22A family members (hOAT1, hOAT3, and hOCT2). Pharm. Res. 24, 811-815. doi: 10.1007/s11095-006-9196-x

Valdes, R., Fernandez-Veledo, S., Aymerich, I., Casado, F. J., and Pastor-Anglada, M. (2006). TGF-beta transcriptionally activates the gene encoding the high-affinity adenosine transporter CNT2 in rat liver parenchymal cells. Cell. Mol. Life Sci. 63, 2527-2537. doi: 10.1007/s00018-006-6240-2 
VanWert, A. L., Gionfriddo, M. R., and Sweet, D. H. (2010). Organic anion transporters: discovery, pharmacology, regulation and roles in pathophysiology. Biopharm. Drug Dispos. 31, 1-71. doi: 10.1002/bdd.693

Visser, F., Vickers, M. F., Ng, A. M., Baldwin, S. A., Young, J. D., and Cass, C. E. (2002). Mutation of residue 33 of human equilibrative nucleoside transporter 1 and 2 alters sensitivity to inhibition of transport by dilazep and dipyridamole. J. Biol. Chem. 277, 395-401. doi: 10.1074/jbc.M105324200

Volonte, C., and D'Ambrosi, N. (2009). Membrane compartments and purinergic signalling: the purinome, a complex interplay among ligands, degrading enzymes, receptors and transporters. FEBS J. 276, 318-329. doi: 10.1111/j.17424658.2008.06793.x

Wallace, L. J., Candlish, D., and De Koning, H. P. (2002). Different substrate recognition motifs of human and trypanosome nucleobase transporters. Selective uptake of purine antimetabolites. J. Biol. Chem. 277, 26149-26156. doi: 10.1074/jbc.M202835200

Wiley, J. S., Smith, C. L., and Jamieson, G. P. (1991). Transport of $2^{\prime}$ deoxycoformycin in human leukemic and lymphoma cells. Biochem. Pharmacol. $42,708-710$

Xiao, J. C., Zhang, T. P., and Zhao, Y. P. (2013). Human equilibrative nucleoside transporter 1 (hENT1) predicts the Asian patient response to gemcitabine-based chemotherapy in pancreatic cancer. Hepatogastroenterology 60, 258-262. doi: $10.5754 /$ hge 12687

Xu, Q., Wang, C., Meng, Q., Liu, Q., Sun, H., Peng, J., et al.(2013). OAT1 and OAT3: Targets of drug-drug interaction between entecavir and JBP485. Eur. J. Pharm. Sci. 48, 650-657. doi: 10.1016/j.ejps.2012.12.024

Xu, Q., Wang, C., Meng, Q., Liu, Q., Sun, P., Sun, H., et al. (2014). The oligopeptide transporter 2-mediated reabsorption of entecavir in rat kidney. Eur. J. Pharm. Sci. 52, 41-47. doi: 10.1016/j.ejps.2013.10.010

Yao, S. Y., Ng, A. M., Cass, C. E., Baldwin, S. A., and Young, J. D. (2011). Nucleobase transport by human equilibrative nucleoside transporter 1 (hENT1). J. Biol. Chem. 286, 32552-32562. doi: 10.1074/jbc.M111.236117
Yao, S. Y., Ng, A. M., Sundaram, M., Cass, C. E., Baldwin, S. A., and Young, J. D. (2001). Transport of antiviral $3^{\prime}$-deoxy-nucleoside drugs by recombinant human and rat equilibrative, nitrobenzylthioinosine (NBMPR)-insensitive (ENT2) nucleoside transporter proteins produced in Xenopus oocytes. Mol. Membr. Biol. 18, 161-167. doi: 10.1080/09687680 118681

Young, J. D., Yao, S. Y., Sun, L., Cass, C. E., and Baldwin, S. A. (2008). Human equilibrative nucleoside transporter (ENT) family of nucleoside and nucleobase transporter proteins. Xenobiotica 38, 995-1021. doi: 10.1080/0049825080 1927427

Zollner, G., Wagner, M., Fickert, P., Silbert, D., Fuchsbichler, A., Zatloukal, K., et al. (2005). Hepatobiliary transporter expression in human hepatocellular carcinoma. Liver Int. 25, 367-379. doi: 10.1111/j.1478-3231.2005.01033.x

Conflict of Interest Statement: The authors declare that the research was conducted in the absence of any commercial or financial relationships that could be construed as a potential conflict of interest.

Received: 26 November 2014; paper pending published: 27 December 2014; accepted: 13 January 2015; published online: 10 February 2015.

Citation: Pastor-Anglada M and Pérez-Torras S (2015) Nucleoside transporter proteins as biomarkers of drug responsiveness and drug targets. Front. Pharmacol. 6:13. doi: 10.3389/fphar.2015.00013

This article was submitted to Drug Metabolism and Transport, a section of the journal Frontiers in Pharmacology.

Copyright (c) 2015 Pastor-Anglada and Pérez-Torras. This is an open-access article distributed under the terms of the Creative Commons Attribution License (CC BY). The use, distribution or reproduction in other forums is permitted, provided the original author(s) or licensor are credited and that the original publication in this journal is cited, in accordance with accepted academic practice. No use, distribution or reproduction is permitted which does not comply with these terms. 